\title{
Lapurdum
}

LAPURDUM Euskal ikerketen aldizkaria | Revue d'études basques |

Revista de estudios vascos | Basque studies review

$8 \mid 2003$

Numéro VIII

\section{Euskal antzerki garaikideaz}

\section{Mari Jose Olaziregi}

URL : http://journals.openedition.org/lapurdum/1167

DOI : 10.4000/lapurdum. 1167

ISSN : 1965-0655

\section{Éditeur}

IKER

\section{Édition imprimée}

Date de publication : 1 novembre 2003

Pagination : 389-426

ISBN : 9782867813436

ISSN : 1273-3830

\section{Référence électronique}

Mari Jose Olaziregi, « Euskal antzerki garaikideaz », Lapurdum [Linean], 8 | 2003, Sarean emana----an 01 mai 2009, kontsultatu 01 mai 2019. URL : http://journals.openedition.org/lapurdum/1167 ; DOI :

10.4000/lapurdum. 1167 


\section{Mari Jose Olaziregi}

Euskal Herriko Unibertsitatea

\section{Euskal antzerki garaikideaz ${ }^{1}$}

\section{Urritasuna, arazoak... eta egungo euskal antzerkiaren gaitzez.}

Euskal antzerkiaren urritasunari buruzko iritzi eta usteak zinez ezagunak dira gurean. Zailtasunez aurkituko dugu irakurleek edo kritikariek gogokoen dituzten liburuen zerrendetan antzezlanik, eta euskal literatura garaikideari buruzko bibliografian antzerkiaren arloa dugu, saiakerarenarekin batera, gutxien aztertua dagoena. Urritasun honek, ziur aski, egungo euskal liburugintzan generoak duen protagonismo eskasean izango du zergatia. 2000. urteko euskal liburugintzari dagozkion emaitzen arabera, literatur liburuaren \% 6,3 dagokio soilik antzerkiari (ik. Jakin 128, otsaila 2002). Ehuneko txikia da hori 1876-1935 urte bitartean generoak izan zuen loraldia kontuan hartuz gero: garaian hartan, literatur liburuaren \% 48,3 zegokion antzerkiari. Orduz geroztik, urrituz joan da euskal liburugintzan izan duen garrantzia, urrituz generoak zuen erakarmena. Hori gutxi balitz, euskal antzerkiaren desagerpenaz mintzo zaizkigun baieztapenak etengabekoak izan dira azken urteotan eta instituzioen dirulaguntzarik gabe, zailtasunez bideratuko lirateke gaur egun programazio desberdinetan eskaintzen diren antzerki ikuskizunak.

Dakusagunez, euskal antzerki garaikidea urria da eta, horretaz gainera, urri aztertua izan da. Herri antzerkiaren baitan bereiz ditzakegun tipologia desberdinak alde batera utziz gero, ikerketa gutxi dira antzerki modernoa hizpide izan dutenak. Ondoko lerroetan adieraziko dugunez, Patri Urkizuren

\footnotetext{
${ }^{\top}$ Artikulu hau $2002 \mathrm{ko}$ udazkenean Euskal Herriko Unibertsitateak deitutako irakasle titular plazetan aurkeztutako txostenaren atal bat da. Atalari zegozkion ariketa didaktikoak izan dira artikulutik kanpo geratu diren bakarrak.
} 
lanetan eskaintzen zaizkigun hurbilpen kritiko-historiografikoak kenduta, eskasak dira oso egungo euskal literatura dramatikoaren inguruko datuak, iruzkinak edo ikerketak biltzen dituzten liburuak. Are gehiago, ikerketa horietan gutxitan aztertzen dira genero dramatikoak bere gain hartzen dituen alderdi guztiak, ez bakarrik alderdi testuala (hori ere sakon aztertzeke dago), baita generoari berari hertsiki datxezkion antzezpenaren inguruko elementu guztiak ere (taldeak, produkzioak, hartzaileak...). Gauzak horrela, etorkizuneko unibertsitate-ikerketek konpondu beharko dute azken 30 urteotako antzerkiaren inguruko ikerketa urritasuna. Bien bitartean, bere mugak onartuz, ondoko lerroetan egungo euskal antzerkiari dagozkion hainbat hausnarketa proposatzen ahaleginduko gara.

\section{Generoari dagozkion zehaztapen teorikoak.}

J.-M. Lasagabasterrek (19832) ongi adierazi zuen bere "Gaurko euskal teatroaren gorabeherak" artikulu ezagunean, antzerki edo teatroak genero bezala duen berezitasun zinez nabarmena. Teatroaren Semiotikaren ekarpenei esker dakigunez, teatro-zeinua konplexua da, batetik, testua, eta bestetik, antzezpena biltzen dituelako. Teatroan biltzen dira, testu mailan, elkarrizketak eta ohar edo akotazio eszenikoak; eta antzezpenean, arlo literarioa eta ez literarioa, indibiduala (idazlea) eta kolektiboa (antzezleak, zuzendaria, eszenagilea... ikusleria). Gizarte-praktika baita teatroa, A. Ubersfeld-ek bere Lire le théâtre (1978) eta L'école du spectateur (Lire le théâtre 2) (1981) modu probokatzailean esan zuen modura, "teatroa ez da mota literarioa, praktika eszenikoa baizik".

Gauzak horrela, teatroaren alderdi guztiak hartu beharko ditu kontuan ikerlariak baldin adierazgarriak diren elementuen berri eman nahi badu. Ildo honetan, Kurt Spang-ek (19913) ere argi azpimarratu nahi izan du antzerki jarduera osatzen duten elementu eta kode aberastasuna:

Hay que librarse "del terrorismo del texto y del terrorismo escénico" (aip. Ubersfeld) porque el drama es por naturaleza el texto junto con su representación; el tex to dramático constituye una especie de partitura sui generis que precisa de la adecuada "ejecución" para poder convertirse en auténtico drama. He aquí también el origen de lo

2Lasagabaster, J.M. (1983) "Gaurko euskal teatroaren gorabeherak", Jakin, 37, 45-60.

${ }^{3}$ Spang, K. (1991) Teoría del drama. Lectura y análisis de la obra teatral, Universidad de Navarra, Iruñea. 
que Anne Ubersfeld llama "art paradoxal" del teatro, puesto que el texto perenne es estímulo y desencadenante de interpretaciones cada vez nuevas y distintas; el drama es creación de un individuo y, sin embargo, se hace imprescindible la colaboración de un colectivo para que cobre vida en la representación. (...) Una ciencia del teatro, una "dramatística" o "teatrología", debe indagar por tanto el teatro como fenómeno plurimedial, (...)

Bistakoa denez, antzerki lan bat ikusten duen edonor segituan jabetzen da entzuten edo ikusten dituen hitz, hots, zeinu, musika, marrazki, irudi... horiek guztiek osatzen dutela artelana, guztiei egin beharko diela jaramon baldin bere harrera behar bezala gauzatu nahi badu. Horretaz gain, antzezpenarekin amaitzen da harrera hori gauzatzeko aukera, testua edonoiz irakur badezake ere, antzezpena une zehatz bati lotua azaltzen baita.

Gauzak horrela, euskal antzerkia izango dugu hizpide ondoko lerroetan, hau da, euskaraz sortua ala ez, euskaraz antzezten dena. Gure iruzkinak jatorriz euskaraz sortutako literatura dramatikoa aztertzera bideratuta egongo badira ere, arreta berezia jarriko dugu azken 30 urteotako euskal antzerkiaren mundu aberatsak bere gain hartu dituen elementu desberdinak aipatzeko: antzeztaldeak, instituzioetatik bultzatu den antzerki-politika, jardunaldi eta topaketak, ikastaroak... Gure hurbilpenak, beraz, muturretako jarrera kritikoak saihestuko ditu: ez gara literatura dramatikoaren irakurketa hutsean geratuko, ezta antzezpenari dagozkion elementuen aipamen hutsean ere. Prozedura honekin lortuko dugu euskal antzerki garaikidearen bilakaera ulertzea, edo gurean hain erroturik dauden hainbat topiko baztertzea, hala nola, euskaraz sortutako antzerki lanen urritasun erabatekoarena. Antzerkiak euskal liburugintzan izan duen lekua murriztuz joan dela egia bada ere, egia da, halaber, 60-70 urteetako euskal antzerki abangoardistak talde-lanak, bat-bateko happeningak... hobetsi zituela eta egile-antzerkia ukitu eta adierazpide berriekin aberastu nahi izan zuela. Kasu gehienetan, Grotowski eta besteren esanak gogoan hartuz, testu dramatikoa talde-sorkuntza prozesuaren ondorena zen emaitza bilakatu zen. Oraindik ere, Ander Lipus-en gidaritzapean, Bilboko Mina Espazioa bezalako eremuetan bizirik dagoen muturreko abangoardismo hori leunduz joan da azken urteotan eta, inguruko herrialdetan gertatu denaren ildotik, 90eko hamarkadan testu dramatikoak berriro ere bere garrantzia aldarrikatzeari ekin dio. Honetaz guztiaz hitz egingo dugu ondorengo puntuetan eta zenbait kontzeptu eta tipologia (absurduaren antzerkia, krudeltasunaren antzerkia, antzerki sinbolista...) argitzen ahaleginduko gara. 
1960-70eko hamarkadetan indar handiz hedatu ziren joera abangoardistetan, eta bereziki, A. Artaud-en lanetatik hasi eta Leaving Theatre bezalako mugimenduetan hedatu zen prozedurari erantzunez, testua baztertu egin zen eta antzezpenari eman zitzaion lehentasuna.

\section{Modernitate osteko antzerkigintzaren ezaugarriak.}

Inguruko literaturetan bezala, instituzioek emandako dirulaguntzei esker bizi da gaurko euskal antzerkia. Aisialdiko ohiturei begiratu besterik ez dago, antzerki emanaldietara zein jende gutxi hurbiltzen den ikusteko. Hortik, antzerki komertzialenak (komedia burges gaurkotua, errebistak, film egokitzapenak...) gurean ere duen arrakasta, ikusleria ziurtatzea bilatzen baitute egungo euskal programatzaile gehienek. 2000 urtean euskaraz estreinatu ziren E. Lindoren Manolito Gafotas (Ados Antzerki Taldea), edo Bariccoren Ozeanoko pianista saritua (Ttanttaka), esaten ari garenaren adibide dira. Horien ondoan, urte berean estreinatutako 8 Olivetti Poetiko (Antzerkiola Imajinarioa) abangoardista... edo berriki estreinatu den $\mathrm{A}$. Iturberen $A i$ ama!, komertzialkeriari ihes egin nahi dioten apustuen adibide ditugu.

Teatro garaikidearen errealitatea ezagutzen laguntzen diguten elementuak ditugu guztiak. Alabaina, modernitate osteko teatrogintiaren bereizgarriak zeintzuk diren aztertu nahiko genuke jarraian. Beste generoetan bezala, azken hamarkadetako antzerki-jardueraren bereizgarririk badagoen, estetika nagusirik gailentzen den. Gauzak horrela, kritikariek honako ezaugarrion arabera deskribatu dute azken urteotako antzerkigintzaren panorama Espainiako nahiz inguruko literaturgintzetan (ik. Floeck, W. (1995); Oliva, C. (arg.) $\left(2002{ }^{4}\right)$.

Eleberrigintzan gertatzen den antzera, errealismo berritua, hirietako egunerokotasunari begiratzen diona (poética de lo cotidiano), eta pertsonaien barrunbean arakatzen duena gailentzen da modernitate osteko teatroan. Teatro europar garaikide honek bere egiten ditu pertsonaien jarduna eteten duten iruzkin metanarratiboak, edo denbora-espazio jolasak, pertsonaia-aktore bikoizketak... 
La historia cede el campo a los problemas personales y cotidianos de las figuras dramáticas. Característico del teatro reciente es la representación de problemas cotidianos típicos, sobre todo de protagonistas jóvenes en el marco de una gran ciudad.. Además, los autores tratan con predilección los problemas de los jóvenes en un entorno marginado (...) El teatro de los años ochenta y noventa es un teatro ciudadano, cuyos diálogos cortos, su rápida sucesión de escenas y su lengua coloquial directa corresponden al ritmo febril de la gran ciudad. (W. Floeck, 1995:34).

Lehenago zehaztutako ezaugarriek egungo teatroaren izaera definitzen laguntzen badigute ere, bada hamarkada desberdinetako bilakaera deskribatzeko funtsezkoa bihurtzen den dikotomia: literatura dramatikoaren, hau da, testuaren gailentasuna defendatzen duen teatroaren aldeko apustua, edo antzezpenean funtsezkoak diren elementuetan arreta jartzen duenaren aldekoa. Bi joeren arteko eztabaidak baldintzatu dute azken 30 urteetako teatrogintza Europan. Jakina denez, 60-70 urteetako teatroak egile-antzerkia baztertu eta abangoardien bidea egin zuen bere. Esan daiteke, 68ko Maiatzak XX. mendearen hasieratik zetozen aire berritzaileak areagotu egin zituela eta bultzada funtsezkoa eman ziola ordurako errotik aldatua zegoen antzerki tradizionalari.

E. Gordon Craig bezalakoen lan berritzaileak edo Alfred Jarry-ren (1873-1907) Ubú errege (1896) antzezlanak abangoardia historikoen aitzindari kontsideratzen dira gaur egun. Jarryren fartsa grotesko probokatzaileak ("Merde!" adierazgarri batekin hasten da obra) irauli egin zituen ordu arte antzerkiak duintzat zituen heroi, arazo, giro sozial eta gogoetak. Antonin Artaud (1896-1948) dugu antzerkiaren antzaldaketaren zutabe nagusietakoa. "Ankerkeriaren Teatroa" gisara da ezagutua berea eta bertan, musika, dantza, mimoa, ikus-entzunezko baliabideak eta abar gehitzen zitzaizkion antzezlanaren oinarrizko testuari. Ikuskizun totala aldarrikatzen zuen Artaudek, eta bere aburuz, teatroak jatorrizko zentzura, erritual edo ospakizunetatik datorkionera, itzuli behar du. Katarsi emozional eta estetikoa eragin behar du ikuskizunak irakurlearengan. Hauexek dira Le Théâtre et son Double (1938) saio ezagunean Artaudek azpimarratu nahi izan zituen ideia nagusiak. II. Mundu Gerraren ostean, Eugène Ionesco-k (1912-1990) bere Kantari burusoila (1950) lanarekin eta Samuel Beckett-ek (1906-1989) bere Godoten esperoan (1952) maisulanarekin, Absurdoaren Antzerkiaren bidez, gizakiaren desola-

Floeck, W. (1995b) "El teatro español contemporáneo (1939-1993). Una aproximación panorámica", in Alfonso de Toro \& W. Floeck (arg.) (1995) Teatro español contemporáneo. Autores y tendencias, Reichenberger, Kassel. 
zioa, hustasuna, ezereza... deskribatu zituzten. Urte horietan, 1950eko hamarkadan, hain justu, sortuko ziren Europa eta Ipar Ameriketan Antzerki Talde Independienteak. Taldeok antzezpenaren gailentasuna, eszenatoki eta ikusleen arteko gertutasuna, elementu plastiko anitzen erabilera, aktoreen balio-aniztasuna (musika, dantza, mimoa... uztartuz).... aldarrikatzen zituzten. Euren artean, Artaudek hasitako bidearen jarraitzaile kontsidera genitzakeen Living Theatre, Grotowskiren Laborategi Antzerkia edo Performance Group delakoa gogoratu beharko genituzke. Horien guztien itzala kausi dezakegu F. Arrabal edo F. Nieva bezalako antzerkigileen lanetan Espainian... edo Euskal Herrian 70eko hamarkadan estreinatu ziren hainbat lanetan (Irrintzi, El rayo colgado de la luna, Tarima taldearen antzerki lanak...). Horretaz gain, gogora dezagun, EATBko (Euskal Antzerki Taldeen Biltzarra) kide aktiboak izan ziren Goaz bezalako taldeek "Grotowski Laborategi Antzerkia" ri buruzko ikastaroak antolatu zituztela 80ko hamarkadan.

Badirudi XX. mendearen azken hamarkadan, testuarekiko atxikimendu handiagoa aldarrikatzen dutela egungo antzeztaldeek. Tradizionalki antzezpenari garrantzi funtsezkoa eman dioten Els Joglars edo La Fura dels Baus bezalako talde kataluniarrek ere itzulera horren adibide ugariak eskaini dizkigute. Gaztelaniazko literatura dramatikoan, kasu, Albert Boadella, Beneti Jornet, Mirales, Nieva, Marsillach, Sanchis Sinisterra edo Cabal bezalako egile ezagunen ondoan, 80ko hamarkadan estreinatzen hasi diren egile berriak kausi ditzakegu: P. Pedrero, E. Caballero, L. Cunillé edo C. Resino. López Mozoren aburuz ${ }^{5}$, 1990eko hamarkadako literatura dramatikoak honako ezaugarriok izango lituzke: zatikatzea, elipsi edo errepikapenen erabilera etengabea, hau da, ikusleen parte hartze handiagoa eskatzen duten estrategien erabilera; bakarrizketa luzeen erabilera; antzerki klasikotik edo ikus-entzunezkoetatik hartutako gaien remake ugariak. E. Pérez Rasillak (19976), berriz, beste generoetan bezala literatura dramatiko garaikidean eklektizismoa dela nagusi azpimarratu nahi izan du. Gaien aldetik, 1960-1970 hamarkadetan nagusi ziren gai sozialen ordez, gizabanakoaren bizipenei, arazo existentzialei, arreta handiagoa ematen dioten lan dramatikoak gailendu dira. Orokorrean, 70eko hamarkadako joera probokatzaile eta abangoardistak ia desagertu egin dira, eta ikuspuntu umoretsua, ironikoa gehienetan, nagusitzen da. Joera errealista da nagusitu dena, eta Beckett aretoaren inguruko egileen artean abangoardia ukituak oraindik nabariak badira ere (jola-

5López Mozo. J. (2002) "La palabra, ave fénix del teatro", in OLIVA, C. (arg.) (2002) op. cit. 257276.

6 Pérez Rasilla, E. (1997) "La escritura teatral, hoy", Ínsula 601-602, 33-35. 
sak, hausnarketa metaliterarioak, bukaera irekiak, egitura zirkularrak...), gero eta ugariagoak dira beste genero edo arteetatik (zinea, telebista...) hartutako lanen remake edo pastitxeak.

\section{Euskal antzerki garaikideari buruzko ikerketak zertan diren.}

Hasieran genioen modura, euskal antzerki garaikideari buruzko azterketa eta ikerlan urritasuna zinez da azpimarragarria beste literatur generoek gurean eragin duten arreta kritikoarekin konparatuz gero. Patri Urkizuk argitara eman dituen ikerlanetan7, nahiz 2000ko otsailean Gasteizko Filologia, Geografia eta Historia Fakultatean egin ziren Euskal Kritikagintzari buruzko I. Jardunaldiak direlakoetan aurkeztu zuen "Euskal antzertiaz ikerketa zenbait" izeneko txostenean (Oihenart 19, 2002), urritasun hori salatu izan du lezoarrak eta etorkizunean eman beharreko pausoak azpimarratu.

"Antzertia 1980-1990" (Jaǩin 61, 1990) izeneko artikuluan euskal antzerki testuen inguruko ikerketa eta argitalpenak aztertu zituen Urkizuk. Egileak zioenez, azken hamarkadetan hainbat euskal antzerkigileren lanak berrargitaratu eta ezagutzera eman dira. Zerrenda horretan aipatzen zituen, besteak beste, S. Baroja, A. Barriola, J. Barbier edo G. Arestiren lanen argitalpenak, edo gerraondoko hiru belaunaldietako kideenak: hala Zubikarai eta Elias-enak; adinez erdibidean kokatzen zituen Haranburu eta Landart-enak, edo egile gazteagoenak: Antza, Mendiguren... Zerrenda horri 1991-1998 artean Piarres Xarritonek Elkarren argitara eman dituen Piarres Larzabalen idazlanak ( $(\boldsymbol{I}$-VII) gehitu beharko genioke. Edonola ere, sorkuntzari dagokion atal hau ez litzateke behar bezala osatua geratuko, baldin Donostia Hiria edo Toribio Altzaga antzerki sariei esker ezagutzera eman diren egile gazteagoen lanak gogoratuko ez bagenitu (ik. Urkizu, P. : 2000, 644-6458). Hor eman dira ezagutzera, gaur egun euskal literatura dramatiko urriaren ordezkari kontsidera genitzakeen hainbat egile interesgarri, hala nola, X. Mendiguren, J. Olasagarre, J.K. Del Olmo, K. Linazasoro, A. Luku, M. Irigoien... Sariketa horietatik kanpo, Susa edo Elkar bezalako argitaletxeetako antzerki-sailak, nahiz Egan bezalako aldizkarien argitalpenetan, urriak dira zinez aurki daitezkeen testuak. Honi dagokionez, azpimarragarria da egun interneten kausi daitezkeela agortuta edo liburu gisara aurki ez daitezkeen hainbat euskal ant-

${ }^{7}$ Ik. Urkizu, P. (1984) Euskal Antzertia, Antzerti, Donostia. (1996) Historia del teatro vasco, Orain, Donostia. 
zerki lan: www.teatroa.com/euskaraz.html. Euskarara itzulitako ondare unibertsalari dagokionez, berriz, Egan, Antzerti Zerbitzua edo Susa-n argitara eman diren liburuez gain, azken urteotan sortu da kezkarik literatura unibertsaleko antzerki lan ezagunak itzultzeko. Halaxe ulertu du EIZIEk eta dagoeneko Literatura Unibertsala bilduman itzuli ditu: Ionescoren Kantari burusoila (2002) eta Shakespeareren Hamlet (2002). Horiez gain, Becketten Godoten esperoan (Alberdania, 2001. Itz. : Juan Garzia) ere, besteak beste, argitaratuta dago.

Orain artean esandakoak sorkuntza atalari badagozkio ere, egungo euskal antzerkiaren inguruko ikerketak ere aipatu beharko genituzke. Gure irakasgaitik kanpo geratzen diren herri-antzerkiari buruzko ikerlanak alde batera utziz, gutxi dira, zinez, azken hamarkadetako euskal antzerkigintza hizpide izan duten ikerlanak. Jakin aldizkariaren 37. zenbakian (1985) kaleratutako artikulu urriez gain, 1982-1986an kaleratu zen Atzerti Berezian kausi ditzakegun iruzkinak, 1986an eta 1997an Primer Acto aldizkariak kaleratu zituen monografikoak; $1997 \mathrm{az}$ geroztik Artez aldizkarian kaleratuz joan diren artikuluak. Urritasun hori leundu dute euskal antzerkiaren historiografian azagutzen ditugun lan urriek. Azken urteotakoak soilik aipatuz, Urkizuren 1996ko Historia del Teatro Vasco liburua eta 2000 urteko "Teatro del s. XX" artikulua salbuespen dira panorama eskas honetan. Bistakoa denez, azken 30 urteotako euskal antzerkia da lan horietan guztietan gutxien aztertu dena eta gutxien diogunean, antzerkiaren alde desberdinak kontuan hartuz, hau da, testua eta antzezpenaren ingurukoa kontuan hartuz, esan nahi dugu. Esan daiteke azken hiru hamarkadetako euskal antzerkiaren inguruko ikerketa zehatz eta sakonak egiteke dirauela: euskal literatura dramatiko garaikidearen azterketa kritikoak, euskal antzerkiaren alderdi desberdinen ikerlanak behar ditugu (euskarazko estreinaldien bilakaera eta joerak, euskal taldeen dinamika, antzerki-politika garaikidearen emaitzak, programazioaren ezaugarriak...). Artikulu honetan proposatzen dugun hausnarketak urritasun hori konpontze aldera egindako saio xumea izan nahiko luke.

\section{Euskal Antzerki garaikidearen diagnostiko baterako: Euskal Antzerki Politika : antzerti, sarea, dirulaguntzak...}

Puntu honetan, euskal antzerkia sustatzeko eta zabaltzeko egin diren ahalegin eta jardueren berri laburtua emango dugu. Besteak beste, 
E. Arozenak "Eusko Jaurlaritzaren antzerki-politika" (Jakin 37, 1985) artikuluan esandakoak, edo P. Urkizuk Euskal Antzertia (1984) liburuan "Antzerti" z esandakoak... edo La década del teatro vasco (Antzerti, 1992) liburuxkan datorren informazioa laburbilduko dugu. Horiez guztiez gain, Eusko Jaurlaritzaren Kultura Sailera jo dugu, azken urteotako dirulaguntzapolitikaren berri izateko eta "Sarea" bezalako erakundeen jarduerei buruzko informazioa lortzeko. 1999, 2000 eta 2001 urteetan "Antzerki-dirulaguntzetarako batzorde teknikoa" delakoaren kide izanak informazio hau guztia lortzea ahalbidetu digu.

\section{Antzerti :}

Jakina denez, Euskadiko antzerki-ekintzak elkartu, koordinatu eta babesteko, eta antzerki-irakaskuntza eta ikerketa aurrera eramateko xedez sortu zuen Kultura Sailak, martxoaren 21eko 49/1983 dekretuaz, Euskadiko Antzerti Zerbitzua. Modu honetan, behiala aldizkari zena, arlo desberdinez osatutako zerbitzua bihurtu zen 1983an. Honako arloak bereiz zitezkeen Antzerti Zerbitzuaren jardunean:

Antzerti Zabalkunderako aldizkaria (1982-1986). Urtean zortzi aldiz irteten zen, bakoitzean antzerki lan bat argitara emanez.

Antzerti Berezia (1982-1986): hiruhilabeteko aldizkaria. 13 ale eman ziren argitara, kolaboratzaile ugarirekin.

Euskal Antzerki Eskola: 1982an sortu zen Antzerti Eskola Dramatikoa. 1. eta 2. mailak Gasteiz, Bilbo eta Donostiako eskoletan irakasten ziren. 3. eta 4. mailako ikastaroak, berriz, Donostiako Eskolan. 1983/84 ikasturtean atera ziren lehenengo 13 antzezlariak, eta aipagarriak dira urte haietan antzeztu zituzten bi antzerki lan ezagun: bata, Goldoniren Arlekino, bi nagusiren zerbitzaria (zuz.: F. Soleri), eta bestea, Euripidesen Troiarrak (zuz. Iturri). C. Ruiz Corral-ek "Enseñanza teatral. El cambio permanente" (ik. Primer acto, 268, 1997) artikuluan ongi azaltzen ditu eskola honek urtetan izan zituen aldaketak eta iskanbilak. Kontua da Antzertik 1993an eskola izateari utzi eta profesionalentzako aholku zentroa bilakatu zela. EHUk hartu zuen bere gain antzerki-irakaskuntza, 700 orduko diplomatura martxan jartzearekin. Horrekin batera, lehenagotik zeuden antzerki eskola eta tailer ezagunek (Getxo eta Basaurikoa Bizkaian; Gasteizkoa Araban eta Errenteriakoa Gipuzkoan) talde profesional desberdinen eskutan jarraitu dute euren irakaskuntza eta formazio eskaintzarekin. 
Antzertiteka: Euskal antzerki lanen liburutegi eta dokumentazio-zentru izatera deitua zegoena.

Antzerti Zerbitzuaren hastapenetako hainbat jarduera (formazio arloa, aldizkarien argitalpena...) desagertuz joan ziren heinean, Eusko Jaurlaritzaren Kultura Sailaren Kultura Sortu eta Zabaltzeko Zuzendaritzak dirulaguntzen xede eta banaketa birmoldatu egin zuen hegoaldean. Hastapenetatik helburu izan duen euskal antzerkiaren sustapen eta zabalkundea bilatuz, honakook dira gaur egun zuzendaritza hurrek bere gain hartzen dituen jarduera nagusiak:

Sorkuntzara bideratutako dirulaguntzak : antzerki-produkzio unitarioen zuzkidurak gora egin du azken urteotan eta 84 milioi pezetako kopurura iritsi zen 2000. urtean. Dirulaguntza horiek honako ataletan banatzen dira: antzerki-testuak sortzera zuzendutakoak, produktore gazteek antzerki-lanak produzitzera bideratutakoak eta antzerkiaren arloko lanbide-heziketa bultzatzera bideratutakoak (azken honetarako, 25 milioi bideratu dira 2000 . urtean).

Zabalkundea Euskal antzerki-taldeen birei babes ematearekin batera, Sailak euskal antzerkiaren kanpoko presentzia bultzatzearen alde egin du apustu, Donostiako Antzerki Feria - sailak sustatu eta bultzatua- eta Fira de Tárrega - Europako hegoaldeko antzerki-feria nagusia- bezalako merkatuen bitartez zabalduz. Jakina denez, feria hauetan euskal konpainiek euren espazioa dute, Kultura Sailak garatua.

Jaialdiak: Antzerki-jaialdiak arte jarduera hau sozializatzeko bide garrantzitsua dira. Sailak hainbat ekitaldi eta jaialdi babesten ditu: Gasteizko Antzerki Jaialdia, Donostiako Antzerki Feria, Eibar, Getxo eta Santurtziko Jardunaldiak, Azpeitiko Euskarazko Antzerki Topaketak eta kale-antzerki, txotxongilo eta abar. 
1992an sortu zen Sarea (Espazio Eszenikoen Euskal Sarea) koordinatzeaz arduratzen da. Gure herriko antzerki-eskaintzaren erdia baino gehiago antzezten duten 34 antzoki ditu atxikita. Hona, jarraian, 2000. urteko txostenetik ateratako emaitza interesgarrienak:

Egituraketa: Euskal Antzokien SAREA Eusko Jaurlaritzako Kultura Sailak, Foru Aldundietako Kultura Sailek eta horrela erabaki duten Udaletxeek osatzen dute, azken hauek baldin eta gutxieneko material teknikoa duen antzokia badute.

\section{SAREA 2000ko ANTZOKIAK}

\begin{tabular}{|c|c|c|c|c|c|}
\hline \multicolumn{2}{|c|}{ Bizkaia } & \multicolumn{4}{|c|}{ Gipuzkoa } \\
\hline Arriaga Antzokia & Bilbao & La Salle & Andoain & Ementeriako Hiria & Enrenteria \\
\hline Barakaldo Anzokia & Barakaldo & Amaia Antzokia & Arrasate & Biteri Kullur Exxea & Hernani \\
\hline Social Anzookia & Bassuri & Bactartxo & Azkoitia & Amaia Kultur Etxea & Irun \\
\hline San Agustin & Durango & Usurbe & Beasain & Manuel Lekuona & K.E. Lasarte \\
\hline Arriola Kulfur Aretoa & Elorrio & Novedades & Bergara & Latxartegi & Legazpia \\
\hline Torrezabal Kultur Etxea & Eimua & Gurea & Billabona & Herri Antzokia & Ordizia \\
\hline Institutuko Areto Nagusia & Victoria Eugenia & Donostia & Santa Ana & Oñati & Oñati \\
\hline Cetxo Antzokia & Getro & Antroki Zahama & Donostia & Leidor & Tolosa \\
\hline Lamiako & Leica & Luganitz & Donostia & Pagoeta & Unetxu \\
\hline Serantes Kultur Aretoa & Sanfurtzi & Gazteszena & Donostia & Aita Mari & Zumaia \\
\hline Zomotza Arretoa & Zomotza & Herriko Antzokia & Elgoibar & & \\
\hline
\end{tabular}

SAREAk sortu zenetik izan duen helburu nagusietariko bat, arte eszenikoen ikusleak osatu eta trebatzeko kalitatezko programazio egonkorra sustatzea izan da.

\section{0ko jardueraren laburpena eta balorazioa}

Ondoren aurkezten ditugun taulek, Sarea-ren 2000. urteko arte eszenikoetako programazio profesional osoa jasotzen dute. Kanpoan gelditzen da musika arloa. 


\section{TAULA}

\begin{tabular}{|l|l|l|r|r|r|r|r|}
\hline \multicolumn{2}{|c|}{ Emanaldiak } & Ikusleak & Kontratazioen & \multicolumn{4}{c|}{ Diru-sarrerak } \\
\hline & & & k0stua & \multicolumn{2}{c|}{ Sarrerak } & \multicolumn{2}{c|}{$\begin{array}{l}\text { Erakundeen } \\
\text { ekarpenak }\end{array}$} \\
\hline $\mathbf{1 9 9 7}$ & 655 & 184.223 & 353.130 .045 & 226.242 .912 & $64 \%$ & 126.887 .133 & 36 \\
\hline $\mathbf{1 9 9 8}$ & 751 & 203.321 & 340.921 .786 & 188.402 .539 & $55 \%$ & 152.519 .247 & 45 \\
\hline $\mathbf{1 9 9 9}$ & 871 & 220.042 & 426.663 .386 & 240.753 .471 & $56 \%$ & 185.909 .915 & 44 \\
\hline $\mathbf{2 0 0 0}$ & 1.084 & 373.297 & 861.248 .336 & 526.723 .606 & $61 \%$ & 334.524 .730 & 39 \\
\hline $\begin{array}{l}\text { Aldaketa } \\
\mathbf{9 9 - 0 2}\end{array}$ & $24 \%$ & $70 \%$ & $102 \%$ & $119 \%$ & & $80 \%$ & \\
\hline $\begin{array}{l}\text { Aldaketa } \\
\mathbf{9 7 - 0 0}\end{array}$ & $65 \%$ & $103 \%$ & $144 \%$ & $133 \%$ & & $164 \%$ & \\
\hline
\end{tabular}

Azken urteotan arlo guztietan (emanaldiak, ikusleak, kostua...) egon den igoera nabarmena da azpimarragarriena.

\section{TAULA. HAUR ETA HELDUENTZAKO PROGRAMAZIOA}

\begin{tabular}{|cccc|}
\hline & Haurrak & \multicolumn{2}{c|}{ Gazte eta helduak } \\
\cline { 2 - 4 } Emanaldiak & $\%$ & Emanaldiak & $\%$ \\
\hline 274 & $25 \%$ & 810 & $75 \%$ \\
\hline
\end{tabular}

3. TAULA. PROGRAMAZIOA ETA IKUSKIZUN-MOTA

\begin{tabular}{|cccccc|}
\hline \multicolumn{3}{c}{ Antzerkia } & \multicolumn{3}{c|}{ Dantza Besterik } \\
\hline Emanaldiak & $\%$ & Emanaldiak & $\%$ & Emanaldiak & $\%$ \\
\hline 930 & $86 \%$ & 77 & $7 /$ & 77 & $7 \%$ \\
\hline
\end{tabular}

\section{TAULA. PROGRAMAZIOA ETA EUSKARA}

\begin{tabular}{|lrlrlrlr|}
\hline \multicolumn{2}{|c}{ Euskaraz } & \multicolumn{2}{c}{ Gazteleraz } & \multicolumn{2}{c|}{ Testurik gabea } & \multicolumn{2}{c|}{ Beste batzuk } \\
\hline Emanaldiak & $\%$ & Emanaldiak & $\%$ & Emanaldiak $\%$ & \multicolumn{2}{c|}{ Emanaldiak $\%$} \\
\hline 291 & $29 \%$ & 594 & $59 \%$ & 65 & $6 \%$ & 57 & $6 \%$ \\
\hline
\end{tabular}


5. TAULA. PROGRAMAZIOA, EUSKARA ETA IKUSLEAK.

\begin{tabular}{|cccc|}
\hline \multicolumn{2}{c}{ Haurrak } & \multicolumn{3}{c|}{ Gazte eta helduak } \\
\hline Emanaldiak & $\%$ & Emanaldiak & $\%$ \\
\hline 207 & $71 \%$ & 84 & $29 \%$ \\
\hline
\end{tabular}

6. TAULA. PROGRAMAZIOA ETA ANTZERKI-TALDEEN JATORRIA.

\begin{tabular}{|cccccc|}
\hline \multicolumn{3}{|c}{ Euskadi Espainia } & \multicolumn{3}{c|}{ Atzerria } \\
\hline Funtzioak & $\%$ & Funtzioak & $\%$ & Funtzioak & $\%$ \\
\hline 487 & $45 \%$ & 522 & $48 \%$ & 75 & $7 \%$ \\
\hline
\end{tabular}

\section{TAULA. GEHIEN PROGRAMATUTAKO IKUSKIZUNAK} (EMANALDI KOPURUA)

\begin{tabular}{|llc|}
\hline Ikuskizuna & Konpainia & Emanaldiak \\
\hline Los emigrados & Txalo & 32 \\
\hline Txio Txioka & Taun Taun & 26 \\
\hline Tricicle 20 & El Tricicle & 25 \\
\hline Rent & Focus & 24 \\
\hline El pianista del océano & Tanttaka & 23 \\
\hline Plisti-plasta & Takolo, Pirritx eta Porrotx & 22 \\
\hline Arte & Yasmina producciones artísticas & 22 \\
\hline No es tan fácil & Tentazioa & 22 \\
\hline Un embajador en apuros & Pedro Osinaga_ & 20 \\
\hline La dama y el cardenal & Txalo & 19 \\
\hline
\end{tabular}




\section{TAULA. GEHIEN IKUSITAKO IKUSKIZUNAK.}

\begin{tabular}{|lll|}
\hline Ikuskizuna & Konpainia & Sarrerak \\
\hline Tricicle 20 & El tricicle & 22.929 \\
\hline Arte & Yasmina producciones artísticas & 19.087 \\
\hline Kale Free & Free Art & 15.000 \\
\hline Visto o no visto & Faemino y Cansado & 14.188 \\
\hline Plisti-plasta & Takolo, Pirritx eta Porrotx & 12.750 \\
\hline IO negritos__ & Enrique Cornejo & 10.125 \\
\hline Bromato de armonio & Les Luthiers & 7.919 \\
\hline La ratonera & Txalo & 7.689 \\
\hline Daaali & Els Joglars & 7.151 \\
\hline Peter Pan & Luis Ramirez & 6.512 \\
\hline
\end{tabular}

Emaitza hauen ostean, hona KULTURA SAILAK egindako zenbait balorazio :

Oso garbia da eskaintza eszenikoaren gorakada. 1999koarekin konparatuz gero, \% 24 gehitu da eskaintza hori. Arriaga Antzokia Sarea-n sartzeak izan du eraginik igoera horretan.

Errealitateak erakusten digu azken 4 urteotan, antzoki berriak sartu direlako, edo zeudenek beren programazioak finkatu dituztelako, eskainitako emanaldiek \% 65eko igoera izan dutela. Honekin batera, antzokietara hurbildu diren ikusleak \% 103, kontratazio kosteak \% 144 eta diru sarrerak \% 133 gehitu dira.

Azpimarratzekoa da, Bilboko Arriagan eta Donostiako Kultura Patronatuak dituen lau antzokietan biltzen dela Sarea-ren programazioaren \% 41 (Kontuan hartu behar da Gasteizko Principal Antzokia gaur egun ez dagoela SAREAn). 


\section{Sariak, topaketak, jardunaldiak...}

Euskarazko literatura dramatikoa bultzatzera bideratutako sariak ez dira oso ugariak. Beste literatur generoekin konparatuz gero, 60ko hamarkadan sortutako Euskaltzaindiaren Toribio Altzaga Saria edo Donostia Hiria Antzerki Saria dira, ezbairik gabe, aipagarrienak gurean (sarituen zerrendak ikusteko, J.-M. Torrealdairen Euskal Kultura Gaur liburura, edo P. Urkizuren artikulura (2000) jo daiteke). Sari horiekin batera, aipagarriak dira azken urteotan sortutako beste zenbait sari, hala nola, 1989an antzerki kultura bultzatzeko eta egile berrien eta talde amateurren lana ezagutarazteko sortu zen Txema Zubia Saria.

Antzerki jaialdi eta topaketei dagokienez, 2000. urtean Euskal Herri osoan hamazazpi izan ziren era guztietako antzezlanak - nazioarteko jaialdiak, kale-antzerkia, umorezkoa, txotxongiloak, dantzak... - eskaini zituzten herri eta hiriak: Donostia, Baiona, Iruñea, Santurtzi, Lekeitio, Zarautz, Leioa, Araia, Barakaldo, Getxo, Azpeitia, Bilbo, Tolosa, Sestao, Irun... Guztiak dira gaur egungo euskal antzerkiak duen bizitasun eta dinamikotasunaren adibide aipagarriak. Edonola ere, azpimarragarria da antzerki eta topaketa horietako gehienak 1975-1985 artean sortu zirela, eta data horiek profesionaltasunaren aldeko apustua egin zuten euskal antzerki taldeei gutxieneko zirkuitu bat emateko ahaleginaz mintzo zaizkigula. Aipatutako urte horietan sortu ziren, kasu: Getxoko Antzerrki Jardunaldiak (1983), Azpeitiko Euskal Antzerki Topaketak (1983-), Santurtziko Antzerki Astea (1976-), Eibarko Antzerki Topaketak (1977-), Pasaiako Antzerki Jardunaldiak (1982-), Baionako Antzerki Festibala (1981-), Donostiako Antzerki Feria (1988-), Tolosako Nazioarteko Txotxongilo Jaialdia (1983-), Euskal Herriko Antzerki Taldeen Jaialdia Lekeition (1988-), Gasteizko Nazioarteko Antzerki Jaialdia (1976-)... Ondoko lerroetan, horien artean ibilbide luzeenetakoa duen Euskadiko Euskal Antzerki Topaketak izango ditugu hizpide, jakina denez, Azpeitian ospatzen direnak eta aurten XX. edizioa egin dutenak.

\section{Euskadiko Euskal Antzerki Topaketak.}

\section{Azpeitia, 1983-2001. Historia laburra.}

Azpeitiko Antzerki Topaketak euskarazko antzerkiaren gune eta talde amateur eta profesionalen nahiz antzerkizaleen elkargune eta ardatz izateko xedearekin sortu ziren 1983ko abenduan. Hasieran, euskara bultzatzea eta 
euskarazko antzerki lanen ekoizpena eta taularatzea laguntzea ziren helburu nagusiak. Gerora, helburuak zabalduz joan ziren eta euskarazko antzerki amateurrari eszenatoki berriak eskaintzea eta antzerki profesionala ere zabaltzen laguntzea bihurtu ziren xede.

1983ko lehen edizioan sei talde amateurrek hartu zuten parte; hurrengo urtean jada bederatzi taldek, horietako hiru ziren profesionalak 1986. urtean lehen Eskola Antzerkiak estreinatu ziren eta urte berean Euskal Antzerkiaren Aldeko Lehen Biltzarra ere egin zen. 1989an Ignacio Rezabal "Potxolo" omendu zen, eta geroztik, ohitura da ekitaldi bakoitzean euskarazko antzerkiaren alde idatzi eta lan egin duten autoreak omentzea. Hurrengo omendua Antonio Maria Labaien izan zen eta bere obrari buruzko liburu bat ere argitaratu zen. 1990etik aurrera, urtero-urtero autore omenduari buruzko liburu bat plazaratzen da. Ildo beretik, omenduak ardatz hartuta, Eskolarteko Irrati Lehiaketak estreinatu ziren 1991. urtean. 1998an, berriz, Familia Antzerkia deiturikoa izan zen berrikuntzarik aipagarriena, antolatzaileek zioten modura, etxetik bertatik hasten baita antzerkiarekiko zaletasuna. Ikus daitekeenez, urteekin, sei sail ezberdin sortuz joan dira Azpeitiko Antzerki Topaketen baitan: antzerki profesionala, antzerki amateurra, eskola antzerkia, omenaldiak eta liburuak, eta ikastetxeen partehartzearekin osatutako irrati-lehiaketak. XIX. edizioa izan da 200lekoa.

\section{Antzerki Profesionala}

Nahiz eta Azpeitian 1983tik ospatu diren Euskadiko Euskal Antzerki Topaketen helburu garrantzitsuenetakoa antzerki amateurrari bultzada ematea izan den, antzerki profesionalak ere izan du bertan leku garrantzitsua. Lehenengo edizioa, 1983koa, talde amateurrekin bakarrik egin bazen ere, 1984an hiru talde profesionalek hartu zuten parte. 1987. urteaz geroztik, hainbat eta hainbat izan dira euren lanak jende aurrean lehen aldiz Azpeitian aurkeztu dituzten antzerki talde profesionalak. Hona, talde profesionalek Azpeitian estreinatu dituzten zenbait antzerki lan ezagun: 


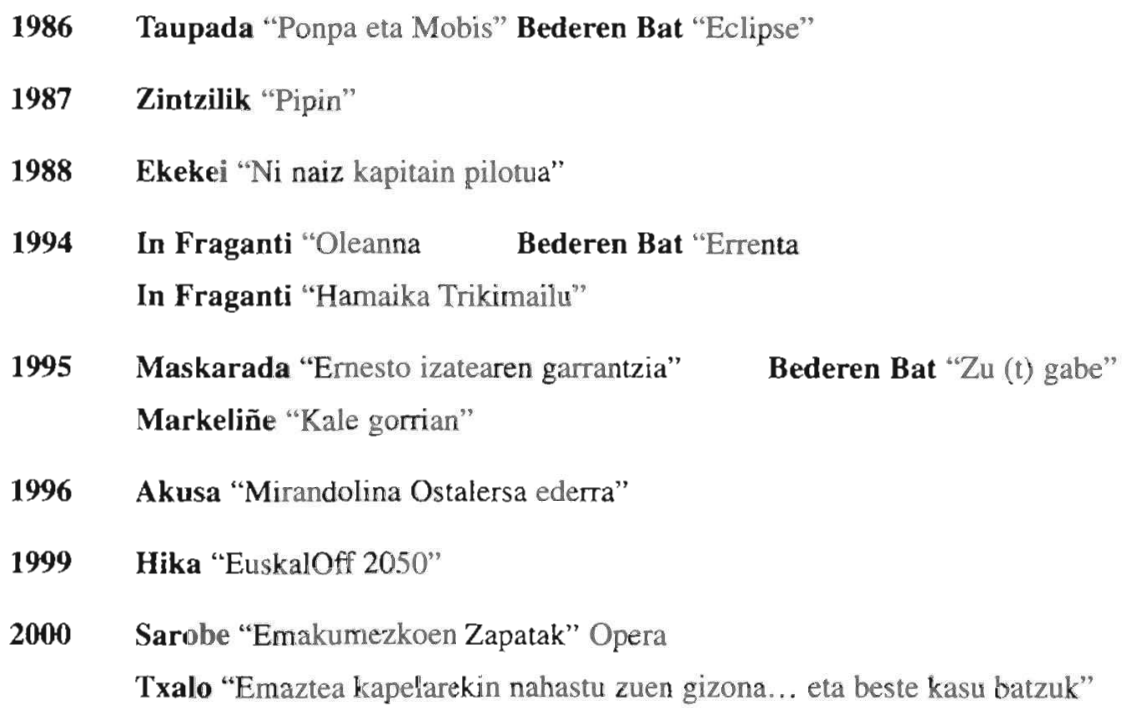

\section{Antzerki Amateurra}

Euskadiko Euskal Antzerki Topaketak egiten hasi zirenetik, Azpeitiak antzerki amateurraren bilgune garrantzitsua izatea lortu du. Euskaraz eginiko kalitate goreneko antzerki amateurraren hedapenean parte hartzea lortu dute topaketek eta, honi dagokionez, hitzaldi, solasaldi eta eztabaidek euskal antzerki amateurraren egoera aztertzen lagundu dute. Hona, amateur mailako estreinaldien zerrenda:

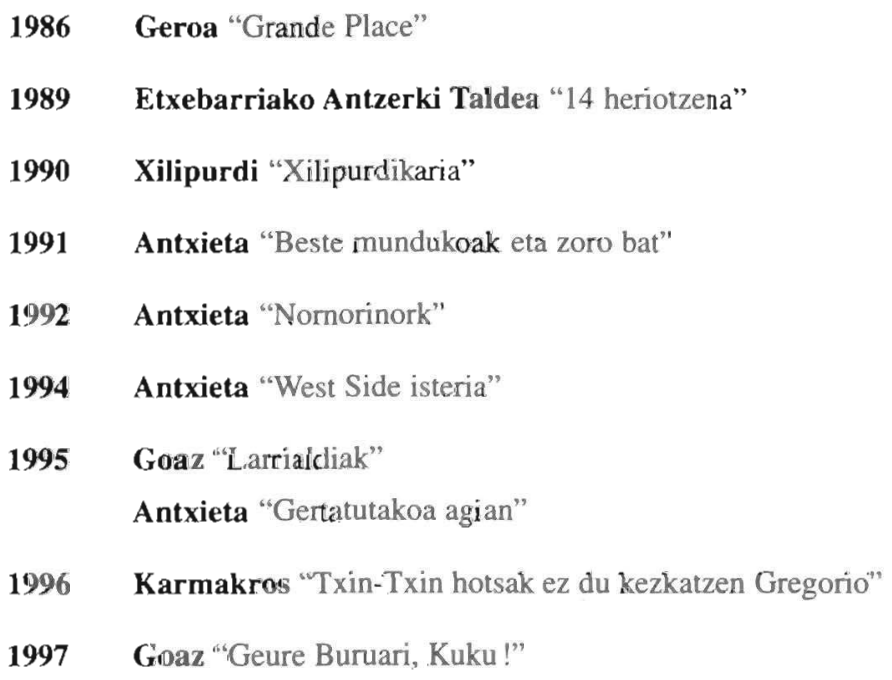


Bordaxuri "Bordaxuri"

Kalakariak "Luma Beroak"

Lakrikun "Zorioneko Oporrak"

Antxieta "Hamar minutu gauerdirako"

1998 Goizeko Izarra "Dizdira, beti, ez da urre"

Lakrikun "Ez dira berdinak, antzekoak baizik"

1999 Kalakariak "Atrakoya"

Lakrikun "Zereko zera zertzen delako zereko zerarekin"

2000 Zurriolako Antzerki Eskola "Gure haurtzaroko lorategia"

Azpeitiko Musika Banda, Aretxabaletako Abesbatza, Julian Barrenetxea

Abesbatza eta Itsasi Dantza Taldea "Baserria"

(euskarazko bertsioaren estreinaldia)

\section{Umeentzako Antzerkia}

Ekimen honek Eusko Jaurlaritzaren Hezkuntza Sailaren dirulaguntza jaso izan du urtez urte. Horrela, Antzerki Topaketetako egitarauaren barnean haurrentzako antzerkia egiten duten talde guztiei laguntza eskaini zaie urtetan.

1984 Orain "Kuluskaka"

Tanttaka "Bai, baina non?"

Taupada "Behin batean... ju, ju, ju..."

1988 Orain "Asufre Koxkorra"

Gasteiz "Supertot"

Taupada "Eta etxekoak zer moduz?"

1992 Takolo, Pirritx eta Porrotx pailazoak "Kokororikoko"

1997 Ixtorio Mixterio "Haurren jokoak eta mixterioak dantzan"

1989 Jake-Mate "Burburú"

1990 Peter Roberts "Marratxo"

Cobaya "Xilibistoren Altxorra"

Gasteiz Antzerkia "Baso Miresgarria"

1991 Kandela Produkzioak "Nadira eta Kristalezko bola"

Tanttaka "Hansel eta Gretel bezala" 
1993 Takolo, Pirritx eta Porrotx pailazoak" Lumak"

1994 Oskorri, Kukubiltxo eta Kepa Junkera "Katuen testamentua"

1995 Kukubiltxo "Jaiotza"

1998 Hika "Xagu kumeak"

Porpol "Xolak badu lehoien berri"

1999 Tutik Ere Clowns/Gari, Montxo eta Jose Lontxo" Ez adarrik jo"

Taun Taun "Txio txioka"

Taupada "Mari sorgin"

2000 Dar-Dar Produkzioak "Alizia bitxikerien lurraldean"

Kukubiltxo "Txirrikiz"

\section{Kale Antzerkia}

Euskadiko Euskal Antzerki Topaketen V. Edizioan, antzerkia aretoetatik kalera ateratzeko ahalegina egin zen lehenengo aldiz. Geroztik, kale antzerkiak bere leku garrantzitsua izan du Euskadiko Euskal Antzerki Topaketetan.

1987

Kukubiltxo "Zokozorrimorria"

Bihar Txontxongilo Taldea "Lantzeko Bandoleroa"

1990 Jake-Mate Antzerki Kolektiboa" Itzala"

Sebastopoleko Titiriteroak "Titiritero Tailerrak"

Kukubiltxo "Jalgi hadi dantzara"

1988 Trapu Zaharrak "Eroak"

Maskarada "Akelarrua"

1989 Hika "Eta ohea egin gabe"

1991 Gog I Magog "Cercavila kalejira"

Gog I Magog "In illo tempore"

Kukubiltxo "Jalgi hadi dantzara"

2000 Trapu Zaharra "Paquetito"

Kukubiltxo "Txirrikiz" 


\section{Omenaldiak}

Euskadiko Euskal Antzerki Topaketen helburu nagusienetako bat euskara eta euskal kultura bultzatzea izanik, 1989. urtean, lehen esan bezala, Ignacio Rezabal "Potxolo" azpeitiarrari omenaldi bat egin zitzaion bere bizitzan euskarazko antzerkiaren alde egindakoagatik. Urte hartatik aurrera, urtero-urtero antzerki lanak euskaraz idatzi dituzten autore esanguratsuenei omenaldiak egin zaizkie: Labaien, Zubikarai, Manuel Lekuona, Anastasio Albisu, Katalina Elizegi, Xabier Lizardi, P. Larzabal, N. Etxaniz, eta Gabriel Arestiri, besteak beste. 1990. urtetik aurrera, omendutako pertsonen gaineko liburuxkak plazaratu dira. Liburu hauen xede garrantzitsuenetakoa euskal antzerkia eskoletara helaraztea izan dela esan genezake. Aspaldiko obra hauek esku-liburu bihurtu ondoren, hainbat eskolatako ikasleen artean banatzen dira, omendutako autoreen lanak eta hauen ikuspegi sozio-kulturala ezagutu dezaten eta euskal antzerkigintzara hurbil daitezen.

\section{Euskal antzerki talde garrantzitsuenen bilakaera ${ }^{9}$.}

Gaur egungo antzerkiaren inguruko datu eta informazio ugari aurki daiteke interneten. Batetik, hortxe dago www.teatroa.com gunea, euskaraz sortutako zenbait antzerki lan ez ezik, itzulpenen berri eta euskal antzerkigileen berri ere ematen duena (www.teatroa.com/nordanor/nordanorg.htm). Horrekin batera, ARTEZBLAI izeneko gunean (ik. http://www.artezblai.com), Euskal Herriko antzoki guztietako (40 inguru) programazioen berri ematen duen ARTEZ hilabetekaria kontsulta daiteke, edo antzerkiaren munduarekin lotutako Artezblai ataria begiratu... edo Yorick atarian antzerki-liburuen erosketa egin. Horiek guztiekin batera, ikerlariak bere eskura dauzka Kultura Sailak Antzerkiaren munduari emandako dirulaguntzei dagozkien berriak (ik. http://www l.euskadi.net/kultura/teatro/teatro e. htm), hainbat talderen web orriak: http://www.markeliñe.com; www.maskarada.net; www.gikitxaro.com... Edo eskola desberdinei dagozkien web orriak:

www.paisvasco.com/sarobe/indexe.html; http://www.gaztenet.com/comarca/barakaldo/cultura/teatro. Horiez baliatuko gara, besteak beste, atal hau osatzeko.

\footnotetext{
${ }_{9}$ Euskal antzeztaldeen atala osatze aldera, artikulu hau idatzi ostean argitara eman den Euskal Antzerti eta Zinea (Etor-Ostoa, 2002) liburuan Juan Agirre Sorondok idatzitako "Euskal antzerki taldeak" atala irakurtzea gomendatzen dugu.
} 


\section{Euskal Antzerki Taldeen Biltzarra (EATB)}

1977 an sortu zen eta, Lukas Dorronsorok adierazi bezala (ik. "Euskal antzerkiaren iraupenerako oinarriak", Jakin 37, 61-86), beren emanaldi guztiak euskaraz eskaintzea soilik erabaki zuten taldeek osatu zuten Euskal Antzerki Taldeen Biltzarra (EATB) delakoa. 1985ean, 16 talde ziren biltzarkide eta horietatik lau soilik ziren profesionalak. Gainera, esan beharra dago, talde profesional horietako batzuk, Maskarada, kasu, beranduago, $1983 \mathrm{an}$, egin zirela biltzarkide. Hastapenetatik, euskarazko zirkuitu bat ezartzearen erronka egin zuen bere EATBk. Lehenengo urteetan, "Galarrotsak" izeneko jaialdiak antolatu zituzten iparraldean eta bertan, ipar nahiz hegoaldeko taldeek hartu zuten parte. Horretaz gain, ikastaroak (Grotowskiren laborategian aritutako ikastaroa 1979an, UEUko ikastaroak 80ko hamarkadan...) eta zirkuituak antolatu zituzten probintzia desberdinetan. Adibide gisara, 1984an Gipuzkoako Foru Aldundiarekin sinatutako kontratua gogora genezake, zeinaren arabera, EAT'B urtean 80 emanaldi egitera konprometitzen zen Gipuzkoan. Edonola ere, urteekin biltzarraren eraginkortasuna ahulduz joan zen (1992an oraindik ikastaroak antolatu bazituzten ere iparraldean), batez ere, Antzerti, Sarea eta horrelako ekimenek biltzarraren beraren premia ahuldu egin zutelako. Horretaz gain, urteek aurrera egin ahala, hizkuntzaren hautua leunduz joan zen eta talde gehienek bi hizkuntzetan eskaintzen dituzte gaur egun emanaldiak.

\section{Honako talde amateurrak bildu ziren EATBn:}

Bordaxuri : 60ko hamarkadan sortua Hazparnen. 1975ean D. Landarten Xuri Gorriak eta... estreinatu zuten. 1976an P. Larzabalen Angles ginelarik. 1977 an Zapeta Xilotik: teatro politiko-soziala. 80ko hamarkadan ikastaro eta estreinaldi desberdinetan hartu zuen parte.

Intxixu: 1968an sortu zen Oiartzunen. Lehen aldi batean, P. Larzabalen Lartaunen Historia, Aralar eta Orria 778 pastoralak egokitu eta bere modura eskaini zituen. Bigarren aldi batean, X. Lete eta E. Arozena gidoigile zituela, Txirritaren Astolasterra, Karlistadarren kronika, Inexa (1970) eta Iparragirre (1980) estreinatu zituzten. Gorputz espresioan oinarritutako antzerkiari heldu zioten batik bat Intxixukoek eta Deusetik Izatera antzerkia muntatu zuten. Intxisuri zor diogu, halaber, Barrutiaren Gabonetako ikuskizuna antzeztu izana eta Benedettiren Pedro eta kapitaina. 
EATBn sartuta zeuden beste talde amateur batzuen artean, iparraldeko Hirurak bat aipatuko genuke, hastapenetan Daniel Landarten lan ugari taularatu zituena eta gerora, G. Irigoien, A. Luku... eta besterenak ezagutzera emateko funtsezko bihurtu dena. Talde honek estreinatu zituen beste lan batzuk: Aldudeko taldea (1974), Iturri (1976) edo Xirrixti-Mirrixti (1982) (azken honek ere D. Landart izan zuen eragile zuzena). Hegoaldean, berriz, gaur egun profesionalak diren Txontxongilo taldea, Intxurre, Txo kolektiboa edo Goaz (1974-) gogoratuko genituzke. Azken talde hau, P. Larzabalen Senperen gertatua antzeztuz hasi zen 1975ean. 1982an, berriz, Haranburu Altunaren Gernika (1982) etorri zen, eta azken urteotan Xabier Mendigurenen hiru lan estreinatu dituzte: Kanpotarrak maisu, Pernando: bizirik hago oraindio eta Larrialdiak. Talde profesionalen artean, berriz, Kukubiltxo edo Taupada bezalakoak aipa genitzake. Lehenengoa, Kukubiltxo, 1977 an sortu zen eta kale-antzerkia izan zen hastapenetatik bere esparrua. Bost urtez amateur modura ibili ondoren, 1982an bihurtu ziren profesional. ETBrekin hainbat saiotan kolaboratu dute (Borobil, Hankaz gora, Banan Bana...), baita Oskorri bezalako taldeekin ere. Ahozko euskal tradiziotik asko edaten duen talde honek berrikuntza izan du beti akuilu. 2001 urtean Ekidazu antzezlana estreinatu zuten, non Oskorriren musika eta Kirmen Uribek M. Zarateren testu batetik egindako egokitzapenak emaitza interesgarririk egin duen. Taupada taldea, berriz, 1977an sortu zen Elgoibarren eta euskal kultura bultzatzea zuen xede nagusi. Bere lan ezagunen artean, 1978ko Oihu Gorrak, Atxagaren Liliput (1980), 1988ko Etxekoak zer moduz?, panpinak eta klownak erabiltzen dituen Zaldi bat, bi kotxe eta 30 ile (1990)... aipa genitzake. Pailazoak, magia... askotan erabili dituzte haurrentzako bere antzezlanetan.

Edonola ere, EATBko kide profesionalen artean talde garrantzitsurik egon bada, hori, dudarik gabe, 1983an bazkide egin zen Maskarada taldea izan zen (ik. www.maskarada.net), euskarazko teatro profesionalaren aitzindaria. Cómicos de la Legua - Kilikilariak taldetik sortu zen ildo euskalduna osatu zuen Maskaradak eta hastapenetako helburua euskal antzerkia soilik eskaintzea izan bazen ere, 90eko hamarkadan antzerki lanak euskaraz eta gaztelaniaz eskaintzen hasi zen. Maskarada 1980an sortu zen Bilbon. Maskaradaren "antzerki haria" zaila da sailkatzen, mota askotako antzerkia landu baitu: kale antzerkia, haur-antzerkia, autore lanak, antzerki-agiria, idazki literarioen moldaketak, kafe-antzerkia, musikalak... Hona, Maskaradak estreinatutako antzerki lanak: 1980.- Jimmy Pottolo eta Zapataria. (Haur antzerkia. Egilea: Bernardo Atxaga.); 1981.- Pantzart. (Kale antzerkia. Euskal inauterietan oinarritua). 1982.- Danbor magikoa. 
(Haur antzerkia. Rodariren ipuin baten moldaketa. Txontxongilo eta hezurharagizko aktoreek antzeztua); 1983.- Tira jira bira kalejira. (Kale antzerkia. Egilea: Maskarada); 1984.- Pistolaren begi zuribeltzak. (Egilea: Dario Fo) ; 1985.- Gastibeltzaren karabinak. (Opereta itxurako ikuskizun musikala. Oskorrik konposatutako kantak. Mark Legasse-ren idazlanaren moldapena): 1986.- Harrizko aresti hau. (Gabriel Arestiren lanean eta bizitzan oinarritutako muntaia. Oskorrirekin batera); 1987.- Gernika 16:39 H.S.O. (Gernikaren bonbaketaren inguruko ikuskizun poetikoa. Hitzak: Edorta Jimenez); 1988.- Telebistarako ekoizpenak: Danbormagikoa. Jimmy Pottolo eta zapataria. 1989.- Kontrabajua. (Egilea: Patrick Süskind.); 1990.Akerlarrua. (Kale Antzerkia. Gaia: akelarrea); 1991.- Marxkarada. (Ikuskizun musikala); 1992.- Logalea Zeukan Ekilibristaren Kasoa. (Haurrentzako antzerkia "Argi beltza" teknika erabiliaz. Egilea: Bernardo Atxaga). 1993.- Monstruo Sakratuak. (Umore Absurdua delakoa. Egilea: Maskarada.); 1994.- Ernesto Izatearen Garrantzia. (Egilea: Oscar Wilde); 1995.- La Importancia De Llamarse Ernesto. (Egilea: Oscar Wilde); 1996.- Landalan. (Oskorrirekin batera); 1997.- El Cartero De Neruda (Egilea: Antonio Skármeta). 1998.- Izarretako Bitakora. (Egilea: Stanilaw Lem). 1999.- Ikaro (Maskarada-J.C.Perez); 1999.- Kaio Luma Zikina (Maskarada- J.-C. Perez.)

\section{Beste antzerki talde batzuk (profesionalak nagusiki).}

80ko hamarkadan, teatro taldeak ugalduz eta sendotuz joan ziren. Urte horietan sortuak dira, 1976an Gasteizen sortutako Teatro Paraisorekin batera, Tarima Taldea (1981ean Basauriko Antzerki Eskolatik sortua), Karraka (1980an Cómicos de la Leguatik sortua eta R. Barea zuzendari zuena) eta Bekereke (1980an Arabako herrixka batean sortua).

Elebitasun Dekretuak eta Antzerti Zerbitzuak bultzada eman zioten euskal antzerkiari, profesionaltasunaren bidetik, ikuskizun elebidunak moldatzen hasi baitziren talde asko. Gaur egun ohikoa den kontu honek, alegia, ikuskizunak, hegoaldean bederen, bi hizkuntza ofizialetan eskaintzea, Ttanttaka eta Bederen-1 taldeak izan zituzten aitzindari. Ttanttaka 1983an sortu zen eta hastapenetatik, Fernando Bernués izan zuen zuzendari. Hernaniko Viteri Aretoan programazio iraunkorra eskaintzen ahalegindu ziren eta 80ko hamarkadakoak dira egun oraindik gogoratzen diren euren antzezlan batzuk: Agur Eire Agur, Brian Friel dramaturgo irlandarraren lana, edo Kontuz, maite zaitut edo Umekeriak bezalako egokitzapenak. 1990an krisialdi bat izan ostean, 3 kide geratu ziren bertan eta arrakastatsuak diren lanak 
antzeztuz jarraitu zuten aurrera: Denok errudun, El florido pensil, Umekeriak, Shakespeare osoa, gutxi gora behera... etab. 1983koa da, halaber, Bederen-1 taldea, Patxi Santamaria zuzendari duena. 1984an bihurtu ziren profesional eta, besteak beste, Celayaren Erreleboa (1989), Sastreren Guillermo Tell... eta Kunderaren Jakes eta Nagusia antzeztu dituzte. Eurei zor dizkiegu, R. Agirreren Errenta eta A. Goenagaren Zu ( $t$ ) gaberen estreinaldiak. Gaur egun profesional munduan dabiltzan beste talde ezagun batzuk: Markeliñe (1984), Porpol (1984), Legaleon T (1986), Bai Teatroa (1988), Hika (1989), Pikor (1989), Ñake (1990), Bekereke edo Ur Teatroa izango lirateke. Talde amateurren artean, Maite Agirreren konpainia, Agerre Teatroa, nabarmendu nahiko genuke hainbat egile unibertsal ezagunen (Beckett, Joyce...) lanak egokitu baitituzte euskaraz nahiz gaztelaniaz, modu zinez arrakastatsuan.

\section{Euskal antzerkiaren bilakaera azken 30 urteetan : testuaren gai- lentasunetik, antzezpenaren gailentasunera.}

Azken 30 urteotako euskal antzerkiaz hitz egiteko orduan, badira gauza pare bat hastapenetatik nabarmendu behar direnak:

a/Euskal antzerkiaren protagonismoa egileetatik taldeetara pasa zela 60ko hamarkadan. Aldaketa honen ondorioz, antzezlan askoren jatorria taldeka egindakoa da eta galkortasun epea duena, hau da, antzezpenekin amaitzen dena. Espainiako eta beste estatu batzuetako egungo antzerkian literatura dramatikoak gero eta garrantzi handiagoa hartu badu ere euskal kasuan, oraindik ere, literatura dramatikoaren eskasia eta oihartzunik eza dira aipagarrienak (ikus Primer Acto-n, 1997ko adierazpenak).

b/Euskal antzerki garaikidearen aldi desberdinak zehazteko garaian, garrantzitsua da manifestu fundazionaltzat kontsideratzen den Bernardo Atxagaren "Euskal Theatro Berriaren Bila" (Anaitasuna, 74-1-31) aldarriak Gabriel Arestiren antzerki irakaspenei zor diena onartzea. Hori horrela bada ere, euskal teatro berriaren oinarriak jartzen ari ziren 60-70ko hamarkada haietan, molde tradizionalagoa zuten antzerki-lanek bazuten oraindik egile eta harrera aipagarririk. Gogora ditzagun, P. Larzabalen Matalas (1968) edo Bereterretxe (1985); edo J. Etxaideren Begia begi truk eta Amaiur (1978), A. Albisuren (1975) Gartzi-Ximeno eta... edo beranduagoko Santa Kruz apaiza gerralari (1997), edo A. M. Labaienen azken lana: Muñagorri (1978), guztiak frankismo osteko teatro historikoaren adibide ditugunak, eta moldez nahiz edukiz aurreko hamarkadetako lane- 
kin haustura nabarmenik eragiten ez zutenak (ik. Urkizu, P.). 70eko hamarkadan hasi zen argitaratzen, halaber, Daniel Landart (1946). Larzabalen jarraitzaile eta iparraldeko antzerkiaren sustatzaile eta dinamizatzaile sutsu honek, Hirurak bat, Xirrixti-Mirrixti... eta hainbat taldek antzeztu dituzten antzerki ezagunak idatzi ditu: Bai ala ez (1969), Noiz (1970), Etxe gabeak (1971), Hil biziak (1972-1973), Xuri gorriak, eta... (1974), Ama (1978).... edo talde-lanean sortutako Etxe sartzea (1976), Mee, mee, ardi kaka mehe (1977) bezalako lanak. Horietan gehienetan, iparraldeko herrixketako nekazal giroa edo mezu politiko esplizitua erraz antzeman daitezke, Landartentzat, "Antzerkia, herri burrukaren mintzoa" baita (ik. Landart, D.: Erranak erran... Elkar, 1981). Askotan, ohiturazko koadroetatik gertu (ik. Mee, mee...), gehienetan, pertsonaiak on/gaizto multzoetan banatuz (ik. Xuri gorriak...) Landarten antzerkia urruti zegoen hegoaldean Arestiren ostean hedatu ziren aire berritzaileetatik.

\section{Aitzindaria : G. Arestiren antzerki modernoa}

G. Aresti dugu, ezbairik gabe, 60ko hamarkadako euskal antzerkiaren berritzaile eta sustatzaile nagusia. R. Saizarbitoriak Lau teatro Arestiar (Lur, 1973) liburuaren hitzaurrean dioskun modura:

[Aresti] Euskal eszenarioetan teatroa eraberritu nahi zuten gazteen beharretara eta ahalmenetara egokitu zen. Teatro berri bat behar zen eta Aresti hura eskeintzen ahalegindu zen (...) Aresti banguardismo kutsuko teatro herrikoi bati lotzen zitzaion, nola hala beste parajeetan inposatzen ari zen teatro integral batetara heldu nahiean" (9-10)

1965ean gaude eta Donostiako Jarrai taldeak (1958-1966) Beste mundukoak eta zoro bat antzezten du abenduaren 13 an Donostian. Hurrengo hilabetean, Xabier Letek hauxe dio Zeru Argia-ko (1966-I-24) orrietan: Arestiren aipatu antzerki lanak euskal antzerki modernoari ematen dio hasiera. Molde tradizional eta xede nazionalistako teatroarekin eten nahi izan zuen Arestik "herri antzerki iraultzaile" gisara kontsideratuak izan diren bere proposamen teatralarekin.

Aresti izango da, Bernardo Atxagak miresmenez aitortu duen modura (ik. AA. VV., Gabriel Arestiren mundua. Erakusketak eta Jardunaldiak, Bilboko Udala-Gipuzkoako Foru Aldundia, 2000), asteasuarraren lehenengo antzerki lanaren, Borobila eta puntua (Lur, 1972), bultzatzailerik sutsuena. P. Telleriaren aburuz (1997), euskal teatro garaikideak G. Arestiri zerbait zor 
baitio horixe zor baitio: berritze eta dinamizatzaile ahalegin erraldoia, nahiz eta, gerora ikusi den modura, Arestiren proposamen teatralek baino eraginkortasun handiagoa izan duten 60-70 hamarkadetan sortuz joan ziren antzerki talde independienteen abangoardismo berriak.

\section{Bernardo Atxaga : euskal teatro berriaren bila esperimentalismoaren bidetik.}

Bernardo Atxaga dugu, euskal literaturaren ibilbide garaikidean poesian nahiz antzerkian modernitate osteranzko ibilbidea markatzen duena. Lehenago aipatu dugun "Euskal Theatro Berriaren bila" manifestuan argi uzten du antzerki berriaren ezaugarrien zerrenda: euskaraz idatzia izan behar du; Euskal Herri osorako egina; euskal gizartearen kontraesan eta arazoekin engaiatua, hau da, errealitateari aurre egingo diona, eta atzerriko ekarpenak (Stanilavsky, Brecht, Roy Hart, Grotowski, Artaud...) nahiz euskal molde tradizionalak (bertsolaritza, pastoralak...) uztartzen jakingo duen teatroa. Berriro ere, berrikuntza zen Atxagak proposatzen zuena.

Urte horietan, 1967tik 1970era, Akelarre taldeak, Luis Iturriren zuzendaritzapean, Hator, Irrintzi eta Gerra Ez antzezten ditu; Intxixuk, Larzabalen lanak egokitu eta proposamen berritzaileagoei egingo die aurre; Donostian, Jarrairen jarraipen kontsidera daitekeen Orain taldea sortzen da; Gasteizen, Felix Petite eragile izango duen Denok taldeak F. Nievaren esperimentalismoa egingo du bere... Bilboko, Cobaya taldeak A. Jarry-ren Ubú probokatzailea antzeztu eta talde sormenari emango dio lehentasuna (Grotowski eta Stanilawsky-ren esanak jarraituz), Durangoko Geroa (1969-) taldeak egile unibertsalen lan ezagunak antzezteari ekiten dio (Brecht, Dario Fo...), eta 1969an, Cómicos de la Legua-Kilikilariak sortzen da Bilbon, R. Barearen zuzendaritzapean. A. Labaienek 50eko hamarkadan Donostia euskal teatroaren hiria izendatu bazuen, 60ko hamarkadan (lehenago aipatu ditugun taldeak salbuespen) Bilbo da antzerkiaren hiriburua.

Eta Bilbon dago Atxaga Cómicos de la Legua-Kilikilariak-ekin kolaboratzen hasten denean. Abangoardismoaren eta teatro independientearen berrikuntzak bere eginez, 15 ikuskizun izango dira Cómicos de la Legua- ekoek, desagertu arte eskainiko dituztenak. Bi meritu egozten dizkio taldeari P. Telleriak (1997110): batetik, ikuskizunak sortzeko molde berria ezarri zuela

$\overline{10}$ Telleria, P. (1997a) "Euskal. Herriko teatroa Gabriel Arestiren garaitik gaur egunera", Entziklopedia Tematikoa, Hizkuntza eta Literatura, Lur, Donostia, 403-437. 
(plastikoagoa, ikusgarriagoa, gorputz espresioari, irudien erabilerari, musikari... garrantzi handiagoa emango ziona); bestetik, Euskal Herrian zehar antzezteko zirkuitu profesionala sortu zuela. Atxagak idazten ditu Kilikilariak-en lan arrakastatsu batzuk: Nafarroa 1500 (euskal egokitzapena), Tripontzi jauna eta Prakaman, kasu. Lehenengoa, Nafarroaren konkistari buruzko maskara eta aktore ikuskizun deigarria izan zen. Gerora, taldea bitan banatu zen 1980an. Batetik, R. Barearen zuzendaritzapean, Karraka sortu zen. Bestetik, Maskarada taldea (ikus aurreko puntua), Atxagaren zenbait lan antzeztuz hasi zena: Jimmy Potxolo eta Zapataria edo Logalea zeukan Trapezistaren kasua haur-antzerkiak, kasu.

Bernardo Atxagaren antzerkigintza definitu beharko bagenu, abangoardia eta esperimentalismoa izango lirateke erabiliko genituzkeen lehenengo hitzak. Jarraian, ahozko tradiziotik hartutako moldeen erabilera aipatuko genuke, bereziki haurrentzako idatzitako antzezlanetan azaltzen zaizkigun bertso, hitz-joko eta errepikapenetan. Lehen esan bezala, Borobila eta puntua (1972) lan sinbolista da bere lehenengo antzerkia. Hastapenetatik geratzen da argi Atxagak eszenografiari ematen dion garrantzia, testuan bertan baitatoz marraztuta aktore desberdinen kokapen eta mugimenduak. Elementu abangoardistak (koloreen erabilera, gorputz espresioa...) eta antzerkiaren tradizioarekin lotzen diren elementuak (korua) nahasten ditu. 1975ean, Panpina Ustela aldizkarian, Antzerki Minimun bat eman zuen argitara, non, A. Jarryren estiloan, publikoa probokatzen zen, hiru pertsonaia estatikoen hitz-jario etengabean. 1976ko Ziutateaz eleberrian, Bilintxi omenaldia izeneko antzezlana eskaini zigun Atxagak, zeinaren krudelkeriak baduen A. Artauden irakaspenen itzalik (ik. M. Antza, "B. Atxagaren orain arteko antzerkigintza: inkurtsio berritzaileak", Susa 1985. 5, 27-37). Bilintxen heriotza da antzezlan honetan irudikatzen zaiguna, eszenografia zuri-beltza eta "triste bizi naiz eta hilko banintz hobe..." bertso-lerro ezaguna errepikatzen duen koruarekin batera. 1980an Kilikilariak-ek antzeztu zuen Prakaman izan zen hurrengo lana. Jarraian etorri zirenak, berriz, Maskarada antzerki-taldearen web gunean kausi daitezke: Jimmi Pottolo eta Zapataria eta Logalea zeukan Trapezistaren kasua. Biak dira haurrentzako idatziak, nahiz eta, zinez, edozein heldurentzat suertatzen diren interesgarri. Lehenengoa, abentura, umore, eta bertsoz betetako testua da. Logalea zeukan... lana, berriz, Kafkaren ipuinetatik gertu egon daitekeen lana (ik. Gosearen artista) kontsidera genezake, eszenografia zinez ausarta ( 2 eszenatoki eta tartean ikusleria) proposatzen duena. 
Evatxo Peron (No llores por mi Euskalerria) antzezlanaren datarik ez dugu. Gerora, Maskaradak 1991eko Gastibeltzaren karabinak lanaren bertsioarekin edo R. Bareak paratu Euskadifrenia (1986) antzezlanarekin egin bezala, pastoralaren egitura darabil Atxagak Eva Peronen bizitza kontatzeko (ik. M. Antza, Susa 5, 1982). 1995ean, beste lau idazlerekin batera, Por mis muertos antzezlana idatzi zuen asteasuarrak, emigrazioa eta kultur mestizaia gai harturik. Geroa eta Sevillako La Jácara taldeen koprodukzioa izan zen. Horiez gain, Atxagaren hainbat testutan oinarritutako antzerkilanak estreinatu dira azken urteotan: Henry Bengoa Inventarium (Hika, 1995), Xolak badu lehoien berri (Porpol, 1999) eta Bambulo (Ados Teatroa, 2001).

\section{0ko hamarkadako euskal literatura dramatikoa : errealismo kritikoa eta teatro historikoa.}

Teatro esperimentalaren aldia gainditu ondoren, euskal literatura dramatikoak azken hamarkada hauetan euskal errealitatera edo iragan denboretako garaietara begiratu du. Aurreko puntuan aipatzen genionari jarraituz, aurreko belaunaldietako egile batek baino gehiagok jarraitu du molde zinez tradizionalean iragan garaietako Euskal Herria goresten duten lanak argitara emanez (Albisu, Josu Arkotxa...), baina urte hauetako ekarpenik aipagarrienak, hurrengo hamarkadan ere argitaratzen jarraitu duten zenbait idazlek eskaini digu.

Birpasa labur hau Luis Haranburu Altuna (1947) idazle eta editorea gogoratuz hasi beharko genuke. 70eko hamarkadan Job (1975, Kriselu) eta Gernika (Kriselu, 1977) antzerki lanak kaleratu ondoren, 80ko hamarkadan drama historiko desberdinak argitaratu dituena: Zumalakarregi (Kriselu, 1986), Sabino (Kriselu, 1986), Loyola (Kriselu, 1986), Lancre (Kriselu, 1987) eta St. Cyran, jainkoa gorderik (BBK, 1992). Egileak darabilen dokumentazio historikoaren balioa baztertu gabe, pertsonaia desberdinak zedarritzeko garaian egiten du huts Haranburuk, Urkizuk esan bezala (2000), gehienetan eskema ideologiko huts baitira bere pertsonaiak.

Urte horietan hasten da argitaratzen, ziur aski azken urteotako egilerik sarituena izango den Xabier Mendiguren Elizegi (1964) idazlea"l. Bere obraz M.J. Ragué-Arias (1996) eta P. Urkizuk (2000) esandakoak laburbil-

"Egilearen ibilbide narratiboaz, ikus Olaziregi, M.J., Euskal eleberriaren historia, LabayruAmorebieta-Etxanoko Udala, 2002. 
duz, salaketa politikoa eta esperimentalismoa akuilu duten antzezlanen aurrean gaudela esan genezake. Kanpotarrak maisu eta Kultur ministrariak ez digu errukirik lanekin Telesforo Monzon Antzerki Saria irabazi zuen 1986an eta Susak elkarrekin eman zituen argitara 1987an. Kanpotarrak maisu (1987) parabola bat da, Erdi Aroan kokatua eta gaurko Euskal Herriaren ispilu izan daitekeena. Kultur ministrariak ez digu errukirik, berriz, fartsa-politiko gisara defini genezake. Biak dira salaketa politikoa ahanzten ez duten antzerki lanak. Debako Goaz taldeak horietako lehena estreinatu zuen. Publikoari gorroto lanarekin 1986ko Toribio Altzaga saria irabazi zuen, eta happening gisako esperimentu formaltzat har genezake, non publikoaren papera egiten duten bi aktoreek ikusleria probokatzea bilatzen duten. Parateatroa, metateatroa... edo A. Artauden "Ankerkeriaren Teatroa" aipa genitzake, B. Atxagak bere Ziutateaz liburuan sartu zuen Bilintxi omenaldia hartan bezala, botereaz, gizakion krudelkeriaz... mintzo zaigun antzerki lana eskaini baitzigun Mendigurenek Publikoari Gorroto lanarekin. Horregatik sartu zuen lan hori, 1987an idatzitako Zabortegia, Hiru jolas gaizto eta Horren maite zaitut lanekin, Elkarrek 1993an argitara eman zuen Ankerki liburuan, Artauden ankerkeriak zeharkatzen duelako Mendigurenen aldi esperimentala. Egileak berak dioenez, liburu horretako antzezlan gehienak tailer eta talde amateurrek antzeztu dituzte. Goaz taldea izan zen, halaber, 1986an idatzitako Pernando, bizirik hago oraindio lana estreinatu zuena. Lan horrek 1988ko Toribio Altzaga Saria irabazi zuen eta, izenburutik antzematen den modura, Pernando Amezketarraren bizitzako pasadizo irrigarriekin osatzen da antzerki lan hau.

Urte batzuetan ezer idatzi gabe egon ostean, Mendigurenek 1992ko Donostia Hiria Saria irabazi zuen Garai (a) da Euskadi lanarekin. Hiru ekitalditan antolatuta dator, pertsonaia ugariz hornitua (dozena bat-edo; hortik, "obra koral" kalifikazioa erabiltzea egileak berak), eta gertakari historiko batean du abiapuntua. 1966ko Aberri Egunean "El Cabra" ren mutilek gerrillari zaharren antzera, mendi arteko herrixka bat hartu eta "askatzen" dute. Ekintza horrek berez ez du luze irauten, ordu pare bat, antzezlan baten denbora, baina Mendigureni aukera eskaintzen dio Euskadi aske bat nolakoa zatekeen kontatzeko. Ezin esan antzezlan itxuraz nahiko klasiko honen helburu eta mezu politikoa ezkutuan geratzen denik, izenburuan bertan obraren mezuaren irakurketa bikoitza eskaintzen baitzaigu. Garai (a) da Euskadi, bi modutan irakur daiteke: "Euskadi Garai da", alegia, benetako Euskadi librea Garai hirian gauzatu zela dioskun mezua batetik, eta "Garaia da Euskadi", aldarri politikoa bihurtzen den izenburua. Kutxaren 1993ko edizioaren atzeko azalean ezin argiago uzten du Mendigurenek bere helburua. "Garai Euskadi 
izan zen bezala, badelako garaia gu geu izateko, eta gure izate hori antzokietan ere erakusteko". Egilearen azken lanak, Hilerri itxia, 1994ko Toribio Altzaga Saria irabazi zuen eta Primer acto (286 zb, 1997) aldizkarian eman zen argitara. Obra honen jatorria Mendigurenek Beasainen ezagutu zuen gertakari batean dago: hilerri zaharra ixtea erabaki zen eta berriagoa eraikitzea beste alde batean. Udaleko bi langilek hilerriak nola husten dituzten kontatzen du antzerkiak, eta gertakari horren harira, hildakoen bizitza-pasadizoak nahiz bi langileen beldur eta sentimenduak kontatzen dira. Baina antzerki lan honetan ezer nabarmentzen bada, mezu eta salaketa politikoa da: ETAko lagun ohi baten atxiloketa, tortura salatzen dituzte antzezlaneko pertsonaiek eta bere ekintzak justifikatzen.

\section{0eko hamarkadako euskal literatura dramatikoa: izen berriak eta joera aberastasuna.}

Azken hamarkada honetan, batez ere indarrean dauden sariketa literario desberdinei esker, izen berriak azaldu zaizkigu euskal literatura dramatiko garaikidearen panoraman. Aurreko hamarkadan argitaratzen hasi ziren egileek jarraitu dute lanak ezagutzera ematen (Atxaga, Mendiguren, Haranburu Altuna...), eta beste literatur generoetan hainbat lan argitaratu dituzten egileak ere antzerki lanak kaleratzen hasi dira: Y. Arrieta, K. Linazasoro, J. Olasagarre, Cillero. Horiei guztiei, antzerki lanak idazten hasi diren aktore ezagunen ekarpena gehitu beharko genieke, hala nola, A. Goenaga edo R. Agirrerena... edo, sariketei esker, hegoaldean ezagunagoak bihurtu diren iparraldeko egile esanguratsuena: Mattin Irigoien, Guillaume Irigoien edo A. Luku, kasu. Bukatzeko, azken urteotan ezagutzera eman diren idazle berrien izenak ere gogoratu beharko genituzke: Mikel Ugalde Ugarte (Bake Biltzarraren ildotik, BBK, 2000; Toribio Altzaga Saria 1999an) edo Alaitz Olaizola Borda (Zereko zera zertzen delako zereko zerarekin, BBK, 2002 ; Toribio Altzaga 2001 Saria), esaterako.

Orokorrean, eguneroko bizitzari edo gizakiaren barrunbeari begiratzen dion antzerkia da nagusi, gehienetan iruzkin metaliterarioz eta hausnarketarako balio duten flash-back ugariz homitua, eszenografia xumea eskatzen duena, hizkuntza aldetik argitasuna eta sinpletasuna bilatzen duena, erritmo azkarrekoa, pertsonaia desberdinen karakterizazioan sakondu nahi duena... Ezaugarri orokor hauezaz gain, 90eko euskal literatura dramatikoaren joerak azpimarratu beharko bagenitu, honako antzerki tipologia honetan laburbilduko genituzke: 
1/Antzerki errealista berritua: hauxe da jarraitzaile gehien dituen joera. Lan hauetan, euskal gizartearen arazo sozio-politiko-kulturalak azaltzen dira, eta eguneroko bizitzan duten eragina aztertzen. Hemen kokatuko genituzke, besteak beste, Mendigurenen Hilerri itxia; iparraldeko konfliktoez mintzo zaizkigun Guillaume Irigoienenen (1967) lanak (bereziki, gosetea gai duen Apetitu on! (1987) antzerkia, eta rugby partidu baten inguruan sortzen den amodiozko istorio zinez lortua antzezgai duen Don Iban eta Ibai Gorri (Elkar, 1991)); A. Lukuren Tu quoque fili; 40 urte inguru dabilen euskal belaunaldiaren desilusioak kontatu dizkigun J. Olasagarre, Mikel Ugalde eta Alaitz Olaizolaren lanak; Enkami Genuaren Ostilarero afaria...

2/Giza-arazoei buruzko antzezlanak : bikote edo belaunaldi desberdinen arteko arazo, etenak, gaizkiulertuak dira hizpide. Gehienetan ukitu existentzialista nabarmena duten lanak dira, gaurko bizitza azkar eta materialis$\tan$ hausnarketa zirrikituak ireki nahi dituztenak. R. Agirre, A. Goenaga, J. Cillero... eta bestek idatzi dituzte molde honetako lanak.

3/Teatro historiko berritua : antzerki lan hauetan, dela teatro sinbolikoaren bidetik (ik. Lukuren: Antso azkarra...), dela kritika soziala egiten duen fartsaren bidetik (ik. M. Irigoienen Amikuzeko toberak (1991), edo Hautsi da Kristala (1997)), dela pertsonaia historiko ezagunen biografia berreskuratuz (ik. K. Del Olmoren Jon gurea... (1998), Aldi joana, Joana (2000)), aurreko urteetakoa baino teatro historiko interesgarriagoa, pertsonaia sinesgarri eta garatuagoak aurkezten dituena, eskaini digute. Eleberrian gertatzen denaren modura, gertakari historiko handietatik ihes egin eta pertsonen historian sakondu nahi duen antzerkia dugu berau, ezagutzen ez dugun iragana azaleratzen diguna.

4/Absurdoaren Teatroa: joera hau oso modan ez badago ere, Karlos Linazasororen Burdindendak merezi du aipamenik. Gaurko gizakiaren bakardadea, deserrotzea... kontatu digu literatura unibertsaleko maisuen ekarpen interesgarriak bere eginez (Aipagarria da, bestalde, literatura unibertsaleko itzulpenen artean, Beckett, Ionesco, Pirandello... eta bestek berriki lortu duten arreta).

5/Ukitu beltzeko komedia irrigarriak: Hemen kokatuko genituzke Pantzo Hirigaray (1957) iparraldeko idazlearen hiru lanak: Beherearta (1998ko Donostia Hiria Saria), Lamindegiko lamiak (2000ko Donostia Hiria Saria) eta Garatenea (2002ko Donostia Hiria Saria). Hiruretan azaltzen zaigu Zakarias Putxapal detektibea, zinez kasu sinple eta ez korapilatsuak argitu 
beharko dituena. Lehenengo lanean, tren bidaia batean kokatzen bazuen mehatxu harrigarriak jasotzen dituen emakumearen kasua, Lamindegiko... antzerki lanak konplexutasun handiagoko istorioa eskaini zigun, hilketa desberdinen inguruan ikertu beharko baitu detektibeak. Hirugarren eta azken lana, Garatenea, izen bereko trinketean pilota partidu bat galdu ostean sortzen den misterioa argitu beharko du Putxapalek. Hiruretan antzeman daitezke baliabide estilistiko eta teatral berdinak: hitz joko ugariak, eszenen alternantzia azkarra, ekitaldi urritasuna, eszenografia sinplea, elkarrizketa irrigarriak, pertsonaiak karikaturizatzeko joera, iparraldeko topikoekin jolastekoa (zuberotarrei buruzko usteak...), hau da, lanok zinez komedia sinple bihurtzen dituzten ezaugarriak.

Ondoko lerroetan horietako zenbait egileren lana iruzkinduko dugu.

\section{1. urteko Donostia Hiria Antzerki Saria irabazi zuen Enkarni} Genuak (1942) Ostiralero afaria (Kutxa, 2001) lanarekin. 1971ean Manolo Gomezekin batera sortutako Txontxongilo taldeko kide ezagun honek 29 liburu eta 21 disko ditu argitara emanak. 1997an, Iruñeko Udalak eta Nafarroako Antzerki Eskolak antolatzen duten Haur eta Gazteentzako Antzerki Testuen Lehiaketa irabazi zuen. Bi ekitalditan antolatutako antzerki lan zinez xumea da Ostiralero afaria eta ezadostasun politikoengatik haserretuta dauden bi anaia dira antzezlaneko partaide nagusiak. Horiekin batera, langabezian dagoen arreba, 16 urteko anaia eta guztien amak osatzen dute antzerki lan honetako familia. Izeba baten heriotzak 40 milioiko herentzia utziko die baldintza batekin: ostiralero elkarrekin afaltzera behartuta egongo dira eta euren arteko desadostasun politikoak ahaztera. Euskal egoera salatu eta elkarrizketarako dugun beharraz mintzo zaigu Genuaren antzerki hau.

Ramon Agirre (1954) aktorea da, Errenta (Kutxa, 1994) antzerkilanaren egilea eta 1994ko Donostia Hiria Antzerki Sariaren irabazlea. Bederen taldeak estreinatu zuen, euskaraz eta gaztelaniaz, 1994an, Ramon Barearen zuzendaritzapean. Endredo komediatik gertu, apartamentu batean bizi den bikote baten arazoek ematen diote hasiera istorioari. Itxurakeria, diruzaletasuna... izango dira Lolak bere senargaia den Teo uztera bultzatuko dutenak. Apartamentua errentan jarri eta Marta aktoresa ezagutuko du Teok, baita zine-munduaren hutsalkeria irudikatzen duen Juan harroa ere. Bi bikoteen patua nahastuz joango da umore, samurtasun eta zinismo ukituak ere badituen komedia honetan. Balio literarioetan sinesten duten antzerkiari zinemunduaren azalkeria kontrajarriz, bi amaiera proposatzen dizkigu egileak: 
bata, Teo funtzionarioaren bizitzari erabateko aldaketa emango diona; bestea, epilogoan iradokitzen zaigunaren ildotik, itxurak gehiago gordetzen dituena.

Juan Karlos del Olmo (1958), ikasketez maisua eta filologoa, irakaskuntzan eta antzerkigintzan (Barakaldoko Antzerki Lantegi Iraunkorreko zuzendari moduan) jardun ondoren, 1993. urtetik aurrera, Donostiako Udalean egiten du lan. 1995ean Innis Fodhla, Irlandako amonaren ipuinak ( $\mathrm{R} \& \mathrm{~B}$ ) ipuin liburua eman zuen argitara eta, orain arte, hiru dira kaleratu dituen antzerki lanak: Jon gurea, Parisen hatzana (1998ko Toribio Altzaga Saria), Aldi joana, Joana (2000. urteko Toribio Altzaga Saria) eta Elurrezko eskeletoa (Hiria, 2002). Guztietan abiatu da ezaguna den pertsonaia historiko/kultural batengandik: Jon gurea, Parisen hatzana antzezlanean, esaterako, Jon Mirandek bere buruaz beste egin aurreko orduak modu dramatizatu eta poetiko batean berreraiki ditu. Bertan lantzen dira egile zuberotarraren alderdi polemiko eta ilunenak: bere ideologia, alkoholzaletasuna,... 6 pertsonaia dira hiru ekitaldiko lan honetan azaltzen direnak: Mirande, Theresa, psikiatra, laguna, pentsalari ezkertiarra eta apaiza. Elkarrizketen bizitasuna eta testuaren poetikotasuna dira, ezbairik gabe, idazle zuberotarraren perfil biografikoarekin batera nabarmentzen direnak. Aldi joana, Joana (2000, BBK, Euskaltzaindia) lanean Joana III. a Albretekoa (1528-1572), Nafarroako erreginaren biografia eta heriotza misteriotsua dira antzerkiaren muina osatzen dutenak. Kalbindar erreformaren zabalkundeaz arduratu zen emakume argi hau (J. Leizarragaren itzulpena lekuko), Nafarroako erresumaren batasunari ere eusteagatik izan zen ezagun. Del Olmoren antzezlanak oso modu orijinalean planteatzen du pertsonaia historiko honen bizitza, lehenengo maila batean, Joana Albretekoaren gaineko antzezlana prestatzen diharduen antzeztalde bat aurkezten baitigu eta iruzkin metaliterarioz hornitutako antzerkia bera aurkezten 2. maila batean. Ekitaldi bakarrean, 5 aktorek 10 pertsonaia desberdin antzezten dituzte, horietako batzuk, Joana Albretekoa, Katalina Medizisekoa, Nostradamus edo Joanes Leizarraga direlarik. Erlijio, botere... gatazken ondoan, Joanaren heriotzaren inguruko misterioa argitu nahi da, A. Dumas-en Margot erregina eleberrian iradokitakoaren ildotik, konplot baten berri emanez. Aurreko lanean bezala, testuaren tonu literarioa, elkarrizketa landuak, pertsonaien karakterizazioa... azpimarratuko genituzke. Elurrezko eskeletoa azken lana Jose Bergamin protagonista duen drama da.

Aitzpea Goenagak (1959), Madrilen, Antzertin eta New Yorken burutu zituen aktore-ikasketak. Hainbat telesaio eta filmetan hartu du parte eta 1992an Murtziako Zine jaialdiko "Paco Rabal" saria jaso zuen "Santa Kruz 
Apaiza" filmean egindako lanagatik. 1995ean Donostia Hiria Antzerki Saria irabazi zuen $\mathrm{Zu}(t)$ gabe lanarekin eta 1995ean Bederen-I taldeak estreinatu zuen euskaraz eta gaztelaniaz. Bakarrizketa bat da $\mathrm{Zu}(t)$ gabe, Ixabel, 60 urteko alargunaren ahotik, entzuten duguna. Duela hilabete galdu du senarra eta orain ia bizitza osoa egin duen etxea utzi behar du. Azken gauzak jasotzen diharduen unean, bakardadeaz, bikote-bizitzaz, senarrarekin bizitutako gazigozoez egiten du hausnarketa eta amaieran, bakarrizketa hori elkarrizketa bihurtzen da, eta eszenatokian bigarren mailan egondako senarraren presentzia benetakoa bihurtzen. Bost ordu Mariorekin ezagun hartan bezala, emakume alargun honen beldur eta bakardadeak dira hizpide ekitaldi bakarrean eta eszenografia xumez bideratzen den antzerki-lan honetan.

Antîn Luku (1959) AEBko San Franciscon jaioa eta Behe Nafarroan euskaltzaletu eta bizi dena, Guillaume Irigoienen lau antzerki eta tobera batean parte hartu zuen, Hirurak bat taldean, 1985-1990 artean. Narraziozko lanak ere baditu argitara emanak: 1998an Botoiletan narrazioa eman zuen argitara (Maiatz) eta 2000. urtean, Euskal Kama Sutra liburuaren eragile eta idazleetako bat izan zen. Bi aldiz irabazi du Donostia Hiria Antzerki Saria: 1996an Tu quoque fili lanarekin (Kutxa) eta 1997an Antso azkarra edo Miramamolinen esmeralda (Kutxa) teatro historiko-sinbolikoarekin. Tu quoque fili antzerki lanean, Baionako burgesiaren kritika zorrotza egiten du eta belaunaldi nahiz klase desberdinen arteko etena zinez egokiro kontatzen. Protagonistak, Baiona handiko familia burges bat dira : aita prokuradorea da, ama, Aldudetarra eta senarraren miresmen itxian bizi dena, zaletasun garestiak dituen alaba ederra eta semea, zuzenbide ikasketak egiten diharduena eta rock talde batean jotzen duena. Semearen lagun musikazale batek koktel bat bota eta aita izango da zigorra ipintzearen arduradun. Aita-seme arteko harremanak txartuz joango dira eta amaiera zinez bortxazkoa izango du istorioak. Hiru ekitaldiko lan honetan, pertsonaiak eta talde sozial desberdinak modu zinez trebean irudikatzen dizkigu Lukuk, elkarrizketa biziak aurkezten, gertakizunak erritmo biziz tartekatzen. Antzerki lan errealista dugu Tu quoque fili, Baionako gizartearen irudi kritiko eta zorrotza eskaintzen diguna manikeismo oroz ihes eginez eta antzerki molde zinez garaikidea proposatuz.

Javi Cillero (1961) itzultzaile eta idazleak aurreko ikasgaietan aipatu ditugun narratiba lanez gain (ik. Eddy Merckxen gurpila, 1994; Norena da Virginia City?, 1995; flash-ak diruditen ipuin laburrez osatutako eta zinemaren aipu aberatsak bereganatzen dituen estilo umoretsu eta ironikoan idatzitako Hollywood eta biok, $1999 ;.$. ), antzerki lan bat du argitara emana: Uztailaren laua, Renon (Kutxa, 1999), 1999ko Donostia Hiria Antzerki Saria 
irabazi zuena. Aitzpea Goenagaren zuzendaritzapean egin zen antzezpena eta 2000. urteko abenduan estreinatu Donostian. Izenburutik bertatik iradokitzen den bezala, doktorego tesia egin zuen hiri berean, hots, Nevadako Renon, kokatzen du Cillerok antzerkia eta bertan kontatzen direnak estatu batuarrentzat hain esanguratsua den egunean, uztailaren 4 an, gertatzen dira. Bost ekitalditan antolatua eta protagonistetako baten, John-en, iragana argitzera datozen lau flash-black-ez hornitua, apurtutako familia euskaldun baten inguruko drama kontatzen du antzerki lan honek. Bere familia abandonatu ostean, artzaintza baztertu eta dadoek, alkoholak eta porrotak gidatu dute hil zorian dagoen John cowboyaren bizitza. Uztailaren lauan, apustu bitxia egingo dio Renoko taberna batean aurkitu duen gazte misteriotsu batek: bere bizitza kontatzearen truke Las Vegasen jokoan galdutako zaldia berreskuratu ahal izango du eta duen gaixotasunak eragindako samina ahaztu. Gazte hori, nola ez, bere semerik gazteena dela jakingo dugu amaieran, eta testuan etengabe errepikatzen den Edipo konplexua dela medio, aita bilatzera helburu ez oso nobleek bultzatu dutela jakingo dugu. Aita-seme arteko solasaldi dramatiko honetan, emigrazioaren drama, John-en iragan garaietako krimen ez aitortuak... azaleratzen joango dira intentsitate handiz. Egungo amerikar euskaldunen erretratu dramatikoa, Las Vegaseko Casinoen nahiz testuan aipatzen diren film eta idazleen (Hemingway) erreferentziekin zipriztindua.

1962an Tolosan jaioa eta Euskal Filologian lizentziatua, bere herriko udal liburutegian bibliotekari dihardu Karlos Linazasorok. Genero ugari landu ditu egileak (poesia, ipuina, eleberria, antzerkia, haur literatura eta iritzi-artikulugintza) eta hainbat sari irabazi ere bai: Lizardi Saria (1990), Irun Hiria (Poesia-1992), Ignacio Aldecoa Saria (1993), Toribio Altzaga Antzerki Saria (1997), Baporea Saria (1997), Donostia Hiria Saria (1998) eta, 2001ean, Haur eta Gazte Literaturako Euskadi Saria Bota gorriak (AnayaHaritza, 2000) ipuinarengatik (dagoeneko, galiziera, gaztelania eta valentzierara itzulia). Egilearen bibliografiari birpasa bat emanez, hortxe dauzkagu, poesian: Udazkeneko karabana erratua (Elkar, 1991); Apunte eta ahanzturak (Kutxa Fundazioa, 1993), Euriaren eskuak (Alberdania, 1995) eta Inoiz izan ez garenotan (2002); haur eta gazteentzako lanen artean, berriz, Altzeta (Alberdania, 1996) eleberria; Besterik gabe, Albina (Ibaizabal, 1991), Ipuin arriskutsuak (Erein, 1993); Gau, gau, gau, J.K. Igerabiderekin batera (SM, 1997); Afrikako oihan ttiki txukun batean (Aizkorri, 1998), Walter Sismoley Eliseoko zelaietan (Elkar, 2000) eta Hugo (Aizkorri, 2000) narratiba lanak; Kartapazioko poemak (Ibaizabal, 1998) eta Hamabi titare (Aizkorri, 1999) gazteentzako poesia-lanak; Burdindenda (Euskaltzaindia-BBK, 1998) 
antzezlana eta, bukatzeko, hona Linazasororen ipuin-liburuak: Eldarnioak (Elkar, 1991), Zer gerta ere (Alberdania, 1994), Ez balego beste mundurik (Alberdania, 2000) eta Ipuin errotikoak (Alberdania, 2001). Egileak dioencz, azken hiru ipuin-liburuok trilogia bat osatzen dute.

Orain arteko antzerki lan bakarrean, Burdindenda. Trajikomedia sasieruditoa ekitaldi bakarrean (BBK-Euskaltzaindia, 1998), bere ipuingintza alderik alde zeharkatzen duten ezaugarriak kausi ditzakegu: absurdoa, umore beltza eta krudelkeria. Bi pertsonaien solasaren inguruan antolatzen da guztia: burdindenda bateko saltzailea eta erosle gaztea. Eszenografia zinez da sinplea eta hastapenetatik bistakoak dira Samuel Becketten Godoten esperoan obrarekin dituen antzekotasunak. Irlandarraren Vladimir eta Estragonen antzera, Linazasororen erosle gazteak bere buruaz beste egin nahi du eta horretarako beharrezkoa zaion soka erostera sartzen da dendara. Sokaren inguruko elkarrizketa luzatu egiten da eta solas absurdo horretan krudelkeria eta bortizkeria bihurtzen dira nagusi. Bi pertsonaien solas horretan jakiten dugu hainbat gertakari eta pertsonaia krudelen berri: burdinazko makila batez semea jotzen duen aita, emaztea hil eta hozkailuan gordeta daukan saltzailea, estoldetan bizi diren gizaki eta animaliak, Estatuaren funtzionario ankerrak, gorputz atalekin trafikatzen duten ijitoak. Eta batez ere, mendebaldeko filosofoei, bereziki, filosofo estoiko eta sofistei, edo tradizio literario nahiz artistikoari egiten zaizkion etengabeko erreferentziek blaitzen dute antzerki-lan hau. Amaiera zinez da harrigarria: saltzaileak dendan gordeta daukan liburutegiaren ikusmenak kenduko baitio gazteari bere buruaz beste egiteko gogoa. Happy-end harrigarri honetan, literatura eta euskal kultura suertatzen dira depresiotik ateratzeko terapia egokien gisara. Hortik, liburuaren atzealdean datozen hitzek hartzen duten zentzu berria: "Lan hau, bistan da, bizirauteko idatzia dago, psikiatraren hitzak ekiditeko". Terapia literario zinez gomendagarria, $1997 \mathrm{ko}$ Toribio Altzaga Saria irabazi zuen Linazasororen lan honek azken urteotako euskal literatura dramatikoaren panoraman bere lekua baitu.

Bigarren Hezkuntzan diharduen idazle arbizuarra da Juanjo Olasagarre (1963). Sorkuntza ez ezik itzulpengintza ere jorratu du, eta horren erakusgarri dugu 1994an argitara eman zuen W.H. Auden-en poemaantologia bikaina. Hiru dira orain artean kaleratu dituen poesia liburuak: Gaupasak (Susa, 1991), Bizi puskak (Susa, 1996) eta Puskak biziz (Susa, 2000). Horiez gain, Mandelaren Afrika (Susa, 1998) bidaia-kronikaren egilea da (gazt.: El Africa de Mandela, Ediciones B, 2000) eta 1995ean Toribio Altzaga Antzerki Saria irabazi zuen Hegazti errariak (Euskaltzaindia, BBK, 1996) antzezlan errealistarena. Azken hau, bost ekitalditan dago antolatuta, 
eta urtezahar egun batean Iruñeko pisu batean elkartzen diren bost pertsonaien solasak antolatzen du bere muina. 35 urte inguruko pertsonaiak dira guztiak bat kenduta, 22 urteko nobio homosexual bat. Horiez gain, Off-eko pertsonaiekin, kartzelan dagoen Miguel Mari eta Lourdesen senargai nigeriarra, Teo, belaunaldi baten argazkia egiten digu Olasagarrek Hegazti errariak antzezlanean. Argiekin jolastuz, hari nagusia ulertzeko argigarriak diren zenbait flash-back eta flash-forward bat sartzen dira testuan. Oraingoan ere, bere poema liburuetan bezala, Nafarroako herrixka txiki bateko gazte belaunaldi baten desilusio politiko eta kulturalak osatzen du antzerki lanaren edukia. Liburuaren atzeko azalean esaten zaigun modura, gazte hauentzat bizitza kartzela bezalakoa da. Benetako kartzela borroka armatuan sinetsi eta preso dagoen Jose Marirentzat; kartzela, bere homosexualitatea onartzeko arazoak dituen Joxeanentzat; kartzela, bikote-proiektuan sinetsi eta asperdura bere egiten duten Patxi eta Marirentzat; kartzela, halaber, preso dagoen senargai ohia-rengandik alde egin eta paperik gabeko nigeriar batekin batu den Lourdesentzat. Istorioak dira guztiak, Sarrionandiaren poema ezaguna parafraseatzen duen izenburuak dioskun modura, hegazti errari gisara iheska dabiltzan 60ko hamarkadan jaiotako gazteen istorio pertsonalak. Guztiaren osagarri, Olasagarrek erreferentzia ugari egiten dizkie belaunaldi honek maite dituen abesti (Lou Reed, Laboa...) eta jarrera sozio-politikoei. Antzezlaneko pertsonaiak perfilatzeko erakutsi duen trebezia, edo elkarrizketen bizitasuna azpimarratu nahiko genituzke obra gomendagarri honetan.

Yolanda Arrieta (1963) idazle, idazketa-tailer koordinatzaile eta literatur animatzaile gisa aritu izan da, eta, egun, Hasiberriak telesailean, platoko gidoilari moduan egiten du lan. Haur eta Gazte literaturako lanak (Nola bizi, zazpi bizi Desclee, 1996; Denboraren kanta kontuak, SM, 1995; Hegaldiak, SM, 1994; Begigorritarren erlojua, SM, 1992; El reloj de los Begigorri, SM, 1992), 1997ko Irun Saria jaso zuen nobela bat (Jostorratza eta haria, Alberdania, 2001), nahiz antzezlanak eman ditu argitara. Horien guztien berri zehatzagoa www.galtzagorri.org web orrian aurki daiteke, bertan, lan bakoitzari buruzko kritika edo erreseina bilduma ere eskaintzen delarik. Antzezlanen artean, Gela txikiko soineko beltz iluna; Gaur ez dago funtziorik (Santurtziko Udalaren Antzerki Laburren Saria, 1991), A eta B = 1?; Lekurik bai? (Donostia Hiriko akzesita 1993an) aipa genitzake. Argitara emandakoen artean, berriz, Badago ala ez dago...? (Kultura Saila, 1992, "Pedro I. Barrutia Antzerki Saria; eskolarako edizio birmoldatua Aizkorriren eskutik 1998an); Atrakoa (Hezkuntza Saila, 1992); Noiz Baina! (Legazpi Saria, 1990; Egan 1995). Bere lan guztiak talde amateurrek estreinatu dituzte eta bereziki garrantzitsua izan zen Lugaritz Kultur Etxean, 
Bihozkadak lanaren estreinaldia 1995ean. Badago ala ez dago...? antzerkilana, 5 ekitalditan antolatutako obra xumea da, Aita Gaiztoaren ipuin tradizionalaren berridazketa kontsidera dezakegun lana. XVII. mendean kokatzen du istorioa eta orduan erretako sorgin baten alabak eta beste sorgin baten semeak Tulo izenburupean ezkutatzen den aita gaiztoa hil beharko dute, tradizioak dioen modura, bekokian arrautza bat apurtuz. Egileak iradokitzen duen eszenografia originalak, eta kantu tradizionalen erabilerak, sorginkeriaren inguruko auziaren bertsio gaurkotua bihurtzen dute obra hau. 